\title{
SYSTEM-WIDE SIGNIFICANCE OF PREDATION ON JUVENILE SALMONIDS IN COLUMBIA AND SNAKE RIVER RESERVOIRS
}

\author{
Annual Report 1990
}

\author{
Prepared by: \\ C. J. Petersen \\ D. B. Jepsen \\ R. D. Nelle \\ R. S. Shively \\ R. A. Tabor \\ T. P. Poe
}

U.S. Fish and Wildlife Services

National Fishery Research Center

Columbia River Field Station

\author{
Prepared for: \\ U. S. Department of Energy \\ Bonneville Power Administration \\ Environment, Fish and Wildlife Division \\ PO Box 3621 \\ Portland, Oregon 97208-3621 \\ Project Number: 90-078 \\ Contract Number: DE-BI79-90BP07096
}




\section{TABLE OF CONTENTS}

ABSTRACT . . . . . . . . . . . . . . . . . . . . . . ii

ACKNOWLEDGEMENTS . . . . . . . . . . . . . . . . . . .

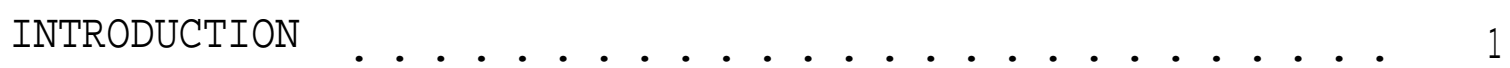

METHODS . . . . . . . . . . . . . . . . . . . 2

RESULTS . . . . . . . . . . . . . . . . . . . . . . . 13

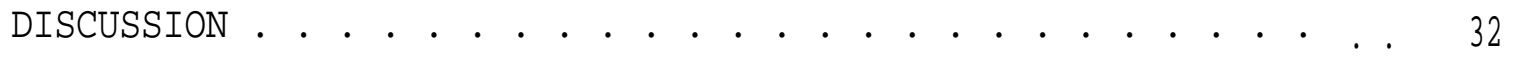

LITERATURE CITED . . . . . . . . . . . . . . . . . . 36

Appendix A - Database Documentation . . . . , . , . . 38

Appendix B - Northern Squawfish Respiration (DRAFT • . 43

Summary Report) 


\section{ABSTRACT}

The consumption rates of northern squawfish (Ptychocheilus oresonensis) preying upon juvenile salmonids were indexed in four reservoirs (Bonneville, The Dalles, John Day and McNary) of the lower Columbia River. During the spring and summer of 1990, over 2,000 northern squawfish were collected from dam forebays, dam tailraces and mid-reservoir locations. Gut content data, predator weight and water temperature were used to compute a consumption index (CI) for northern squawfish. Stomach contents of smallmouth bass (Micronterus dolomieui), walleye (Stizostediog vitreum), and channel catfish (Ictalurus punctatus) were also collected.

Juvenile salmonids were found in 435 of 1,598 northern squawfish guts analyzed. Besides salmonids and other preyfish, crustaceans formed a significant portion of the diet. Mollusks, insects and plant material were also observed in the diet at certain locations.

The CI of northern squawfish varied by season and location. At most locations, summer CI's of northern squawfish were higher than in the spring. The highest CI's were observed during summer in the tailraces of McNary (7.5) John Day (4.0) and Bonneville Dams (3.9). Northern squawfish collected in forebays had intermediate CI's while fish collected in mid-reservoir locations had the lowest CI's. Northern squawfish from the boat restricted zones within tailrace and forebay locations had the highest CI's (maximum 11.2). Reservoir-wide northern squawfish CI's (excluding boat restricted zones) ranged from near zero (Bonneville and The Dalles) to 0.6 in John Day reservoir during the spring; the CI range in the summer was zero to 0.2. Efforts to match sample collection with times of highest juvenile salmonid passage were successful except during July at the Dalles and Bonneville Reservoirs. Consumption indices were moderate to high at several locations even when passage was relatively low, suggesting salmonid predation rate by northern squawfish was not always a function of prey density. Future work will integrate 
consumption index results with predator abundance data (ODFW) to allow a ranking of sampled areas according to estimated loss of juvenile salmonids to northern squawfish.

\section{ACKNOWLEDGEMENTS}

We appreciate the field and laboratory help of Milton Hunter and Matt Mesa. Sampling coordination was facilitated by the Fish Passage Center, particularly Margaret Filardo, whom we thank. We also thank the Army Corp of Engineers for permission to sample near the dams and Steve Vigg, Craig Burley, and Tony Nigro of the Oregon Department of Fish and Wildlife for many helpful discussions. Roy Beaty, Lance Beckman and Margaret Filardo provided useful comments on an earlier draft of this report. Bill Nelson and Bill Maslen (BPA) helped in numerous ways, all of which are appreciated. 


\section{INTRODUCTION}

The U.S. Fish and Wildlife Service (FWS) and the Oregon Department of Fish and Wildlife (ODFW) recently completed a six year study to determine the significance of predation on juvenile salmonids in John Day Reservoir (Poe and Rieman 1988). Study results provided estimates of juvenile salmonid losses to predators which indicated that predation may account for the majority of previously unexplained losses of juvenile salmonids in John Day Reservoir (Rieman et al. 1988). Continuing need for predation research has been designated as high priority by several regional committees and agencies including: (1) the Northwest Power Planning Council ((section $403(d)$ (1)) of the 1987 Columbia River Basin Fish and Wildlife Program): (2) the Water Budget Evaluation - Reservoir Mortality Technical Work Group (TWG minutes of January 27, 1989 meeting); and (3) the 1989 Predator-Prey Modeling Workshop (Fickeisen et al. 1990).

Although predation was significant in John Day Reservoir, we don't know if predation is a significant mortality factor in other Columbia River reservoirs. Because predation management is an ongoing program (Nigro et al. 1990) we also need to: (1) establish baseline data on predator abundance and consumption rates in other reservoirs to evaluate the effectiveness of predation management actions: (2) determine where predation management actions should be implemented: and (3) further develop predation models to help evaluate predation management and to predict cumulative impacts of predators on juvenile salmonid survival throughout the system.

In 1989 a collaborative study of the FWS and ODFW was initiated to develop a predation index to estimate the relative magnitude of juvenile salmonid losses to predators in reservoirs throughout the Columbia River Basin. Development of the index was completed in 1990 and detailed descriptions of the analytical, field, and laboratory techniques for a consumption rate index for northern squawfish (Ptvchocheilus oreaonensis) may be found in Petersen et al. (1990); corresponding methods for 
abundance indexing may be found in Vigg and Burley (1990a).

This report presents the results of indexing northern squawfish consumption rates upon juvenile salmonids during their 1990 out-migration through four reservoirs in the lower Columbia River.

\section{METHODS}

Field Methods

Field sampling for 1990 was completed at 14 locations from Bonneville Dam tailrace through the upper reaches of McNary reservoir and Ice Harbor Dam tailrace in the Snake River (Figure 1 and Table 1). For each reservoir, sample "locations" were selected that represented a forebay, mid-reservoir and tailrace area (Figure 2). Within each location, 24 transects were established, each transect being approximately $500 \mathrm{~m}$. At forebays and tailraces of each dam, 4 of the 24 transects were within the boat restricted zone (BRZ) and 20 were outside the BRZ - 10 being on each side of the river for an approximate distance of $6 \mathrm{~km}$. To facilitate interpretation of results, the position of transects in each dam tailrace and forebay BRZ is shown in Figure 3.

Dam, or project, operations were adjusted to allow sampling within the BRZ and around ice trash sluiceways, spillgates, and powerhouse outflows. Sampling occurred immediately after any project operation change, so gut contents of captured predators should be reflective of typical operating conditions.

A minimum target catch of 30 northern squawfish per day at each location was established (see Petersen et al. 1990); however, around dams the minimum target catch was broken into two units: 15 per day in the BRZ and 15 per day outside the BRZ. Sampling was initiated 90 minutes before sunrise at all locations. The target predator was northern squawfish; smallmouth bass (Micropterus dolomieui), walleye (Stizostedion vitreum), and channel catfish (Ictalurus ounctatus) were also 
Table 1. Sampling locations and dates for northern squawfish Consumption Indexing, 1990. Tr=Tailrace, Fb=Forebay, Mr=Midreservoir, and Up=Upper reservoir.

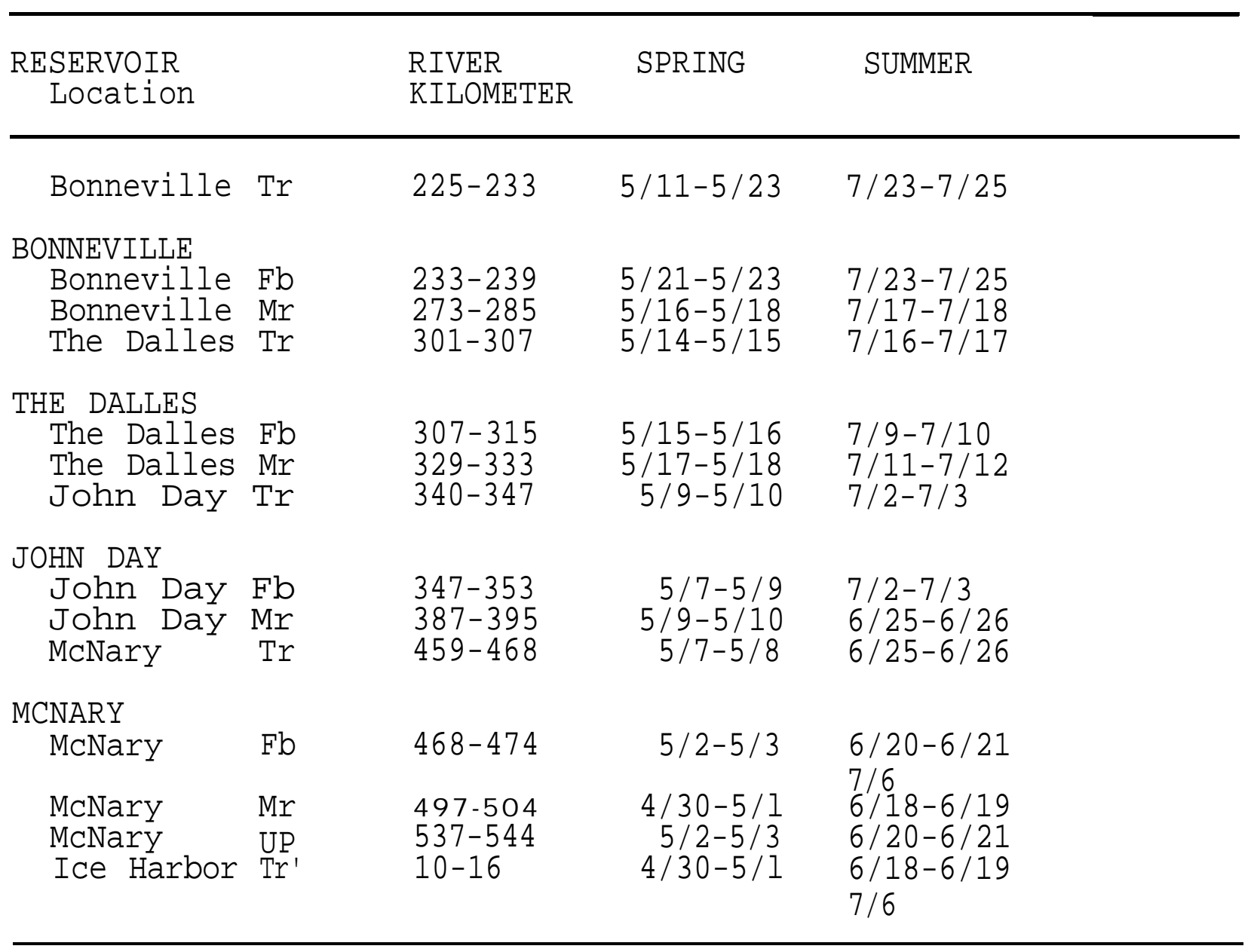

Snake River 


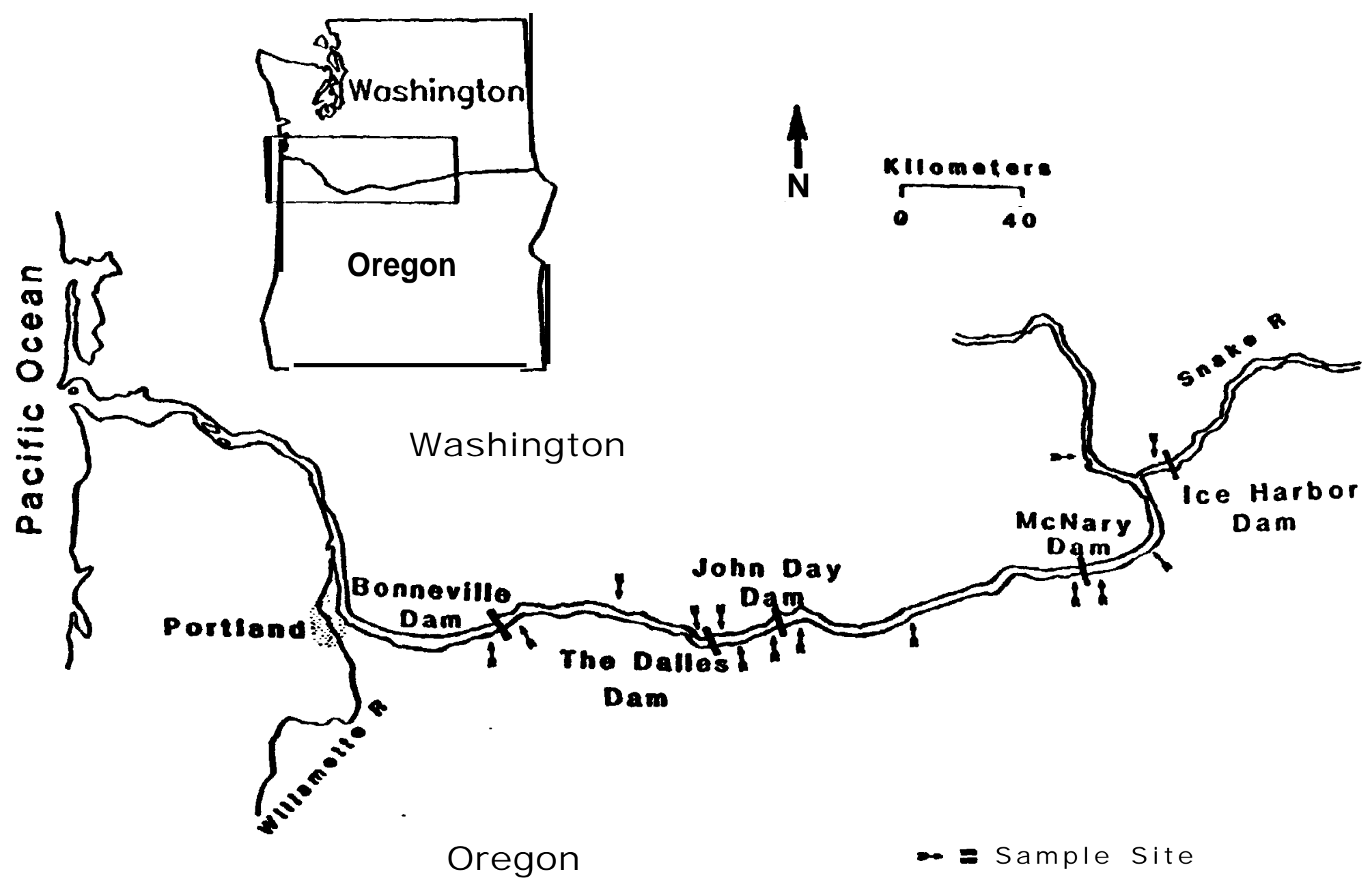

Figure 1. Sampling locations (arrows) for Consumption Indexing during 1990. See Table 1 for specific location information. 
Text Descriptor

Locations

Reservoirwide

BRZ only

\section{Sample Pooling Pattern}
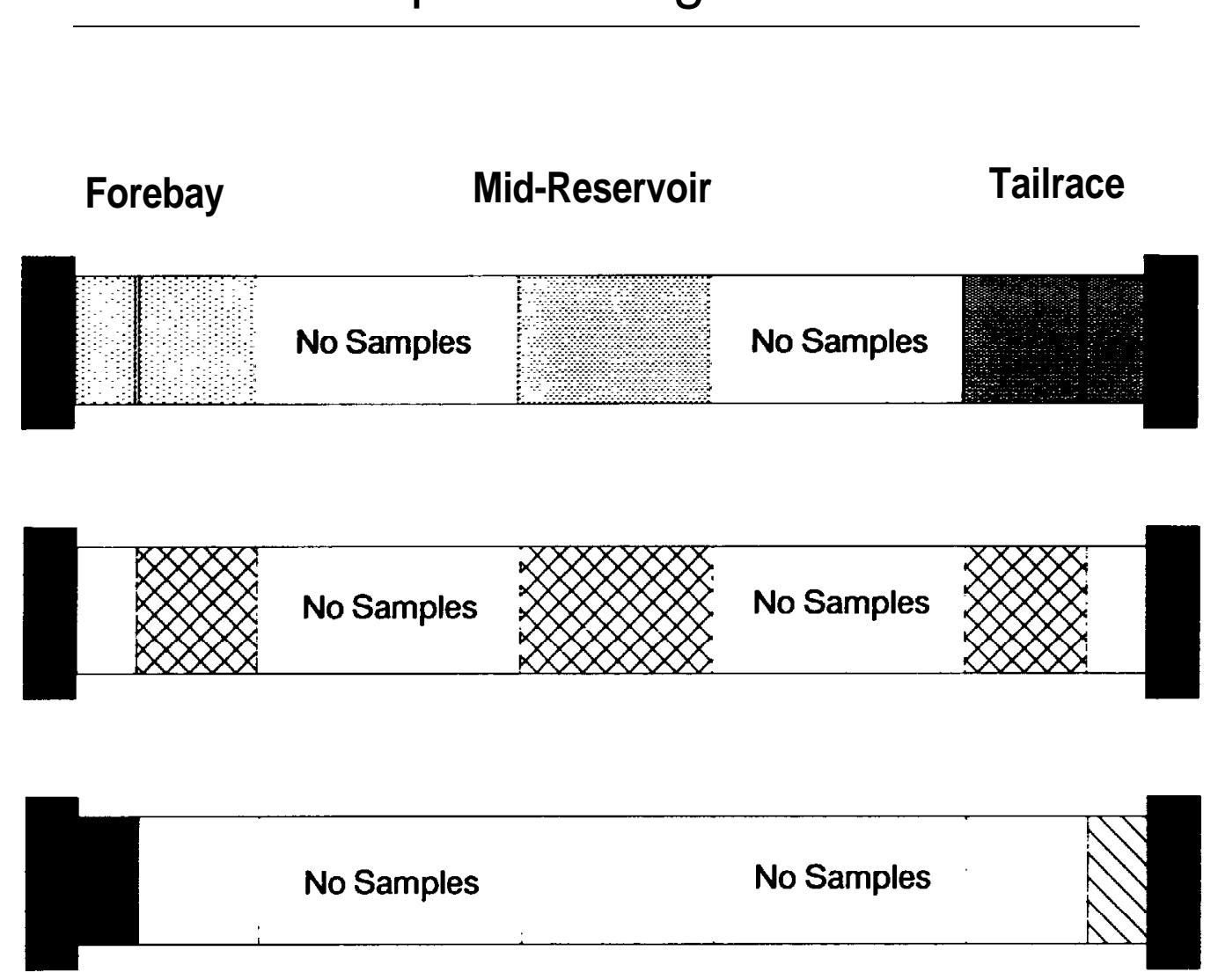

Figure 2. Sample pooling patterns for northern squawfish consumption index (Cl) and diet analyses. Each horizontal diagram represents a simple reservoir, bounded by two dams, in the lower Columbia River. For a particular analysis, data were pooled from areas of the reservoir having the same fill-pattern in the diagram. Diagrams are not to scale.

\begin{tabular}{c} 
Text \\
Table \# \\
\hline Cl Diet
\end{tabular}

\section{$3 \quad 788$}

$6 \quad 11 \& 12$

$49 \& 10$ 

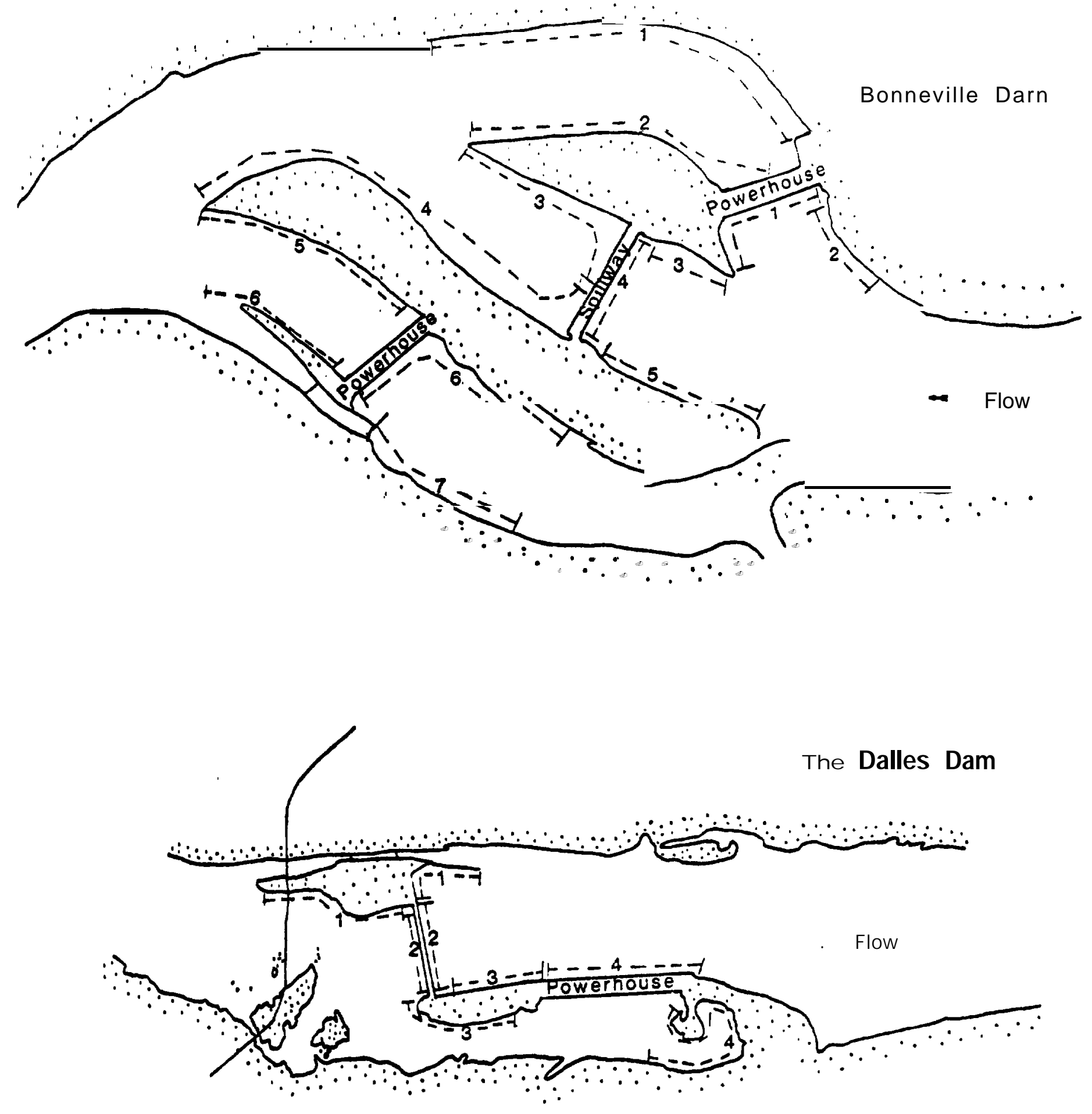

Figure 3. Location of 1990 sampling transects in the Boat Restricted Zones (BRZ) of each dam tailrace and forebay. Upriver is on the right in all drawings. 


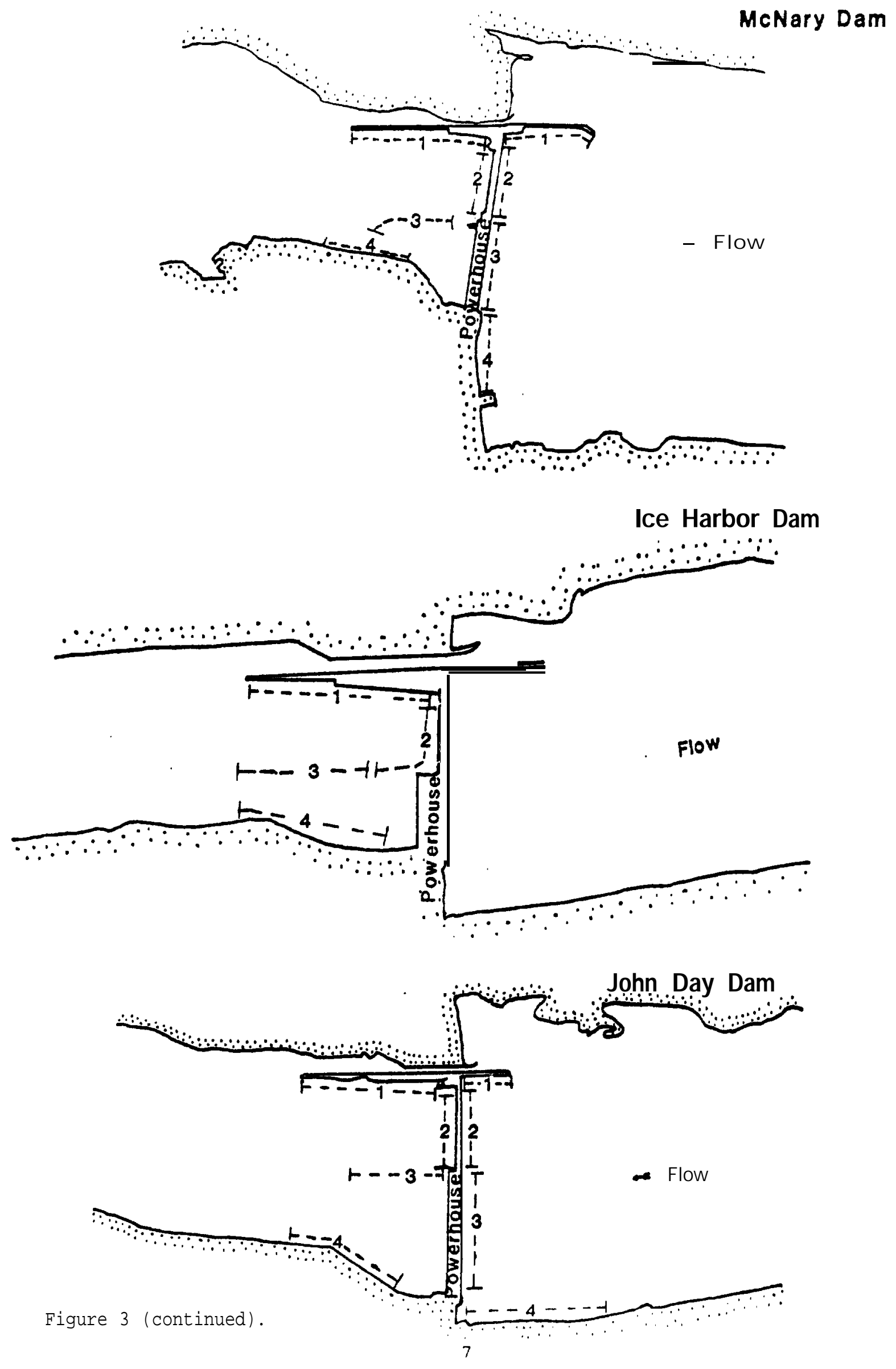


collected for gut sampling.

Two 18-ft Smith-Root' electrofishing boats were used to capture predators, which were retained alive in circulating live wells until processing of gut contents. Transects were electrofished for 15 minute intervals with the first six transects chosen randomly; additional, discretionary transects were fished to maximize catch of northern squawfish. Electroshocking was briefly stopped during sampling to allow in situ recovery of adult salmonids and white sturgeon, which had been incidentally shocked.

Northern squawfish were given a lethal dose of MS 222; data were collected on fork length (FL, nearest $\mathrm{mm}$ ), weight (nearest 5 or $10 \mathrm{~g}$, depending upon fish size), sex, and state of maturity. Scales, otoliths, and opercles were removed for age and growth information. Gut contents of northern squawfish over $250 \mathrm{~mm}$ FL were taken using techniques described in Petersen et al. (1990). Walleye, smallmouth bass, and channel catfish $2200 \mathrm{~mm}$ were anesthetized using MS 222; fork length, weight and scales (pectoral spines of channel catfish) were taken and stomachs were pumped with a modified Seaburg stomach sampler (Seaburg 1957). All gut or stomach contents were placed in plastic bags and kept on ice until freezing; samples were kept frozen until laboratory analysis.

Laboratory Methods

In the laboratory, gut samples were thawed and removed from the sample bags. Intestinal parasites, fat, and other material not ingested were discarded. Gut contents were examined with a magnifying lamp and divided into major prey taxa groups (i.e., fish, crustacean, mollusks, insects, plant and other). Each prey group was blotted by placing the sample on tissue paper for $30 \mathrm{~s}$, weighed to the nearest $0.01 \mathrm{~g}$ and returned to the sample bag.

In order to speed laboratory processing of gut contents, a

\footnotetext{
'Mention of brand names does not constitute endorsement by the U. S. Government.
} 
digestive enzyme technique was used (Petersen et al. 1990). The enzyme solution was prepared using lukewarm tapwater, 2\% (by weight) strength pancreatin ( $8 \mathrm{x}$ porcine digestive enzyme) and $1 \%$ (by weight) sodium sulfide. The solution was poured into sample bags until contents were submersed. Contents were briefly stirred to ensure all surface areas were in contact with the digestive enzyme. Samples were then placed in a desiccating oven at $40^{\circ} \mathrm{C}$ for $24 \mathrm{hr}$. After all flesh was digested, the contents were rinsed through a 425 micron (\#40) sieve with tap water. A dissecting microscope and forceps were used to remove diagnostic bones (primarily cleithra, dentaries, and opercles) from the samples. Diagnostic bones were identified (salmonid, sculpin, or other preyfish), paired to enumerate prey fish consumed, and preserved in labeled vials with 95\% ethanol.

Field and laboratory data were stored in a relational database, which is described in Appendix A.

Consumption Index

Detailed methods and index derivation for the northern squawfish CI were presented in Petersen et al. (1990); an abbreviated description of the $\mathrm{CI}$ is presented here for completeness.

The estimated number of salmonids consumed per day by an individual predator, $p$, can be expressed as:

$$
c_{p}=\sum_{i=1}^{n} 1 / \text { (Evacuation time for prey item } i \text { ) }
$$

or,

$$
C_{p}=\sum_{i=1}^{n} 1 / D 90_{i}
$$

where $\mathbf{c}_{\mathbf{p}}$ is consumption rate (number of salmonids. individual northern squawfish ${ }^{-1} \cdot$ day-1 $\left.^{-1}\right), \mathbf{D}^{9} \mathrm{O}_{\mathrm{i}}$ is number of days to $90 \%$ digestion for salmonid prey item $i$, and $n$ is total number of salmonids found in the gut. Using $90 \%$ digestion time, rather than 100\%, avoids the problem of non-digestible prey parts that 
may remain in the gut for extended periods. Equation (1) is equivalent to:

$$
C_{p}=\sum_{i=1}^{n}\left(24 / \mathrm{T} 90_{i}\right)
$$

where $\mathrm{T} 90$, is number of hours to $90 \%$ digestion for the ith salmonid prey item. T90, was calculated by Beyer et al. (1988) and modified by Rieman et al. (1988) to:

$$
T 90_{1}=1147 * M_{i}^{0.61} * T^{-1.60} * W_{p}^{-0.27}
$$

where $\mathbf{M}_{\mathbf{i}}$ is meal size ( $g$ ) at time of ingestion of salmonid prey item $i, T$ is water temperature $\left({ }^{\circ} \mathrm{C}\right)$, and $w_{p}$ is predator weight (g). Substituting equation 3 into 2 and rearranging gives:

$$
C_{p}=0.0209 * T^{1.60} * W_{p}^{0.27} * \sum_{i=1}^{n} M_{i}^{-0.61} \quad(4) \text {. }
$$

Equation 4 provides an estimate of daily salmonid consumption per northern squawfish, but still requires estimation of meal size $(\mathrm{M}$,$) through intensive gut analysis and complicated data$ analysis. The following formula was chosen as a CI, based upon simplicity of data required and percent variance explained:

$$
\text { CI }=0.0209 * \mathbf{T}^{1.60} * \mathrm{MW}^{0.27} *\left[\text { MTsal } * \text { MGutwgt }{ }^{-0.61}\right]
$$

where $\mathrm{T}$ is water temperature, $\mathrm{MW}$ is mean predator weight $(\mathrm{g})$, MTsal is mean number of salmonids per predator, and MGutwgt is mean gut weight ( $g$ ) per predator. All variables in CI are averaged over all predators in a sample: CI is the consumption index for a collection (sample) of predators.

The CI for northern squawfish, as derived above, isnot meant to be a rigorous method for estimating the number of juvenile salmonids eaten per day by an average predator. The CI is based upon the simple idea of meal turnover times and does not consider such aspects of consumption as diel feeding pattern and 
evacuation rate of prey. In an analysis of data from John Day Reservoir (Petersen et al. 1990), the consumption rate of northern squawfish (CR - juvenile salmonids.predator ${ }^{-1} \cdot$ day $\left.^{-1}\right)$ was related to CI by:

$$
\log _{10}(C R)=1.17 * \log _{10}(C I)-0.41 \quad N=86 \quad r^{2}=0.89 .
$$

Distribution characteristics of the northern squawfish CI were computed by a bootstrap resampling technique (Efron and Tibshirani 1986; Petersen et al. 1990). For each sample of $\mathrm{N}$ predators, a computer program randomly selected $\mathrm{N}$ individual predator records and calculated a new CI. Five hundred CI's were computed for each CI distribution; preliminary studies showed that variances and confidence bounds were stable with 500 samples. The number of predators per bootstrap sample was set to the original sample size (N), or 60 if $N$ was greater than 60 .

Consumption Index (CI) and diet summary analyses for northern squawfish were done by pooling sample data in three different patterns (Figure 2). The rationale for the "reservoirwide" and "BRZ only" analyses (Figure 2) is within the Results section.

Bioenergetics Index

A bioenergetics index (BI) of northern squawish consumption rate, which would complement the direct $\mathrm{CI}$, has been under development and testing (Petersen et al. 1990). The BI uses a general bioenergetics model of fish growth (Hewett and Johnson, 1987, 1989), parameterized to northern squawfish, to estimate consumption rate for a time period. The BI has not yet been calculated for northern squawfish in the mainstem Columbia River reservoirs because we have not completed ageing subsamples of the predators from each reservoir; ageing work is currently underway. Two aspects of bioenergetic modeling of northern squawfish will be reported here: 1) Age determination methods, and, 2) parameter refinement for the model.

Scales were collected from all northern squawfish $\geq 250 \mathrm{~mm}$ 
FL caught during 1990. Approximately 15-30 scales were collected from the area below the posterior base of the dorsal fin and above the lateral line. Scales were prepared for mounting by placing them into a petri dish containing warm water and cleaned with a fine brush. Approximately 4-6 non-regenerate scales per fish were selected, placed on labeled gum cards and heat pressed onto acetate. Scale impressions were projected using a microfiche projector at 42x. Scales were read and ages assigned according to the methods outlined by Bagenal and Tesche (1978) and Jearld (1983). Location of annuli and scale edge were marked on strips of paper to provide a permanent record of the scale reading. Two scales per fish were read by two independent readers. In the event that a reader could not assign the same age to two scales from the same fish, or the two readers assigned different ages to a fish, both readers would collectively age that fish and resolve any discrepancies. Scale ageing techniques were coordinated with ODFW.

In addition to determining ages with scales, opercles and otoliths were collected and used to compare ages assigned to individuals by scale readings. Collection, preparation, and reading of opercles followed methods given by McConnell (1951) and Scoppettone (1988). Otoliths were mounted on glass slides with hot glue and ground to the focus with fine grit emery paper. As in the case with scales, ages were determined by two independent readers and differences were resolved collectively.

Previous studies with the northern squawfish bioenergetics model showed a high sensitivity in model output (accumulated juvenile salmonid consumption in $g$ ) to respiration parameters (Petersen et al. 1990). Respiration parameters specific to northern squawfish were not available for the initial model implementation, so parameter values from related species or "generic" values were used (Hewett and Johnson 1987, e.g.).

Because of the high model sensitivity and lack of speciesspecific respiration parameters, we considered research on northern squawish respiration rates important. A collaborative study with Joseph Cech, Jr. (University of California, Davis) on 
the effects of temperature and fish size upon basal respiration rate was conducted during July, 1990. Data from this study will be used to refine respiration parameters in the northern squawfish bioenergetics model. Results of the respiration study will be submitted to a peer-reviewed journal; a draft report of study results is included as Appendix B.

\section{RESULTS}

\section{Catch Summary}

In the 1990 consumption index field sampling season a total of 2367 predators were captured. Northern squawfish accounted for 85\% (2017) of the catch of the four target predators. Other predators collected were smallmouth bass (13\%, $n=310)$, walleye ( $1 \%, \mathrm{n}=26)$ and channel catfish $(<1 \%, \mathrm{n}=14$ ) (Table 2).

of the 2017 squawfish captured 40\% were collected from the Bonneville Dam tailrace and forebay. The numbers of northern squawfish captured per reservoir generally decreased from Bonneville Reservoir up-river. Northern squawfish fork lengths ranged from 154-481 mm (mean=336 mm, $\mathrm{n}=551$ ) for males and 231$570 \mathrm{~mm}$ (mean=412 mm, $\mathrm{n}=1413$ ) for females: weights ranged from 40$1420 \mathrm{~g}$ (mean=478 $\mathrm{g}, \mathrm{n}=551$ ) for males and 130-2450 g (mean=949 g, $\mathrm{n}=1411$ ) for females.

Sex ratio of the northern squawfish catch was $70 \%$ females, 27\% males, and 3\% undetermined. Catches of females were generally higher near the dams than at mid-reservoir locations, except for Ice Harbor Dam tailrace BRZ (summer) where males made up 58\% of the catch. Ninety-nine percent of the northern squawfish collected in the spring had developing gonads. During summer, $48 \%$ of the females had developing gonads, $16 \%$ were ripe and $32 \%$ were spent. Of males collected during the summer, $10 \%$ had developing gonads, $75 \%$ were ripe and $12 \%$ were spent.

Smallmouth bass were collected in all of the reservoirs and the Bonneville Dam tailrace (Figure 4); however, smallmouth bass were not found in abundance within the BRZ's of the dams. Upriver from Bonneville Dam, the proportion of smallmouth bass in 
Table 2. Number of predators collected during northern sguawish CI sampling, 1990. N=Number, M=Male, F=Female, U=Unidentified sex, $\mathrm{SMB}=$ Smallmouthbass, WAL=Walleye, $\mathrm{CHC}=$ Channelcatfish, Tr=Tailrace, $\mathrm{Fb}=$ Forebay, Mr=Mid-reservoir, and Up=Upper reservoir.

\begin{tabular}{lcccccc}
\hline RESERVOIR & & & & & \\
Location & NORTHERN & SOUAWFISH & WAL & CHC
\end{tabular}

\section{SPRINO}

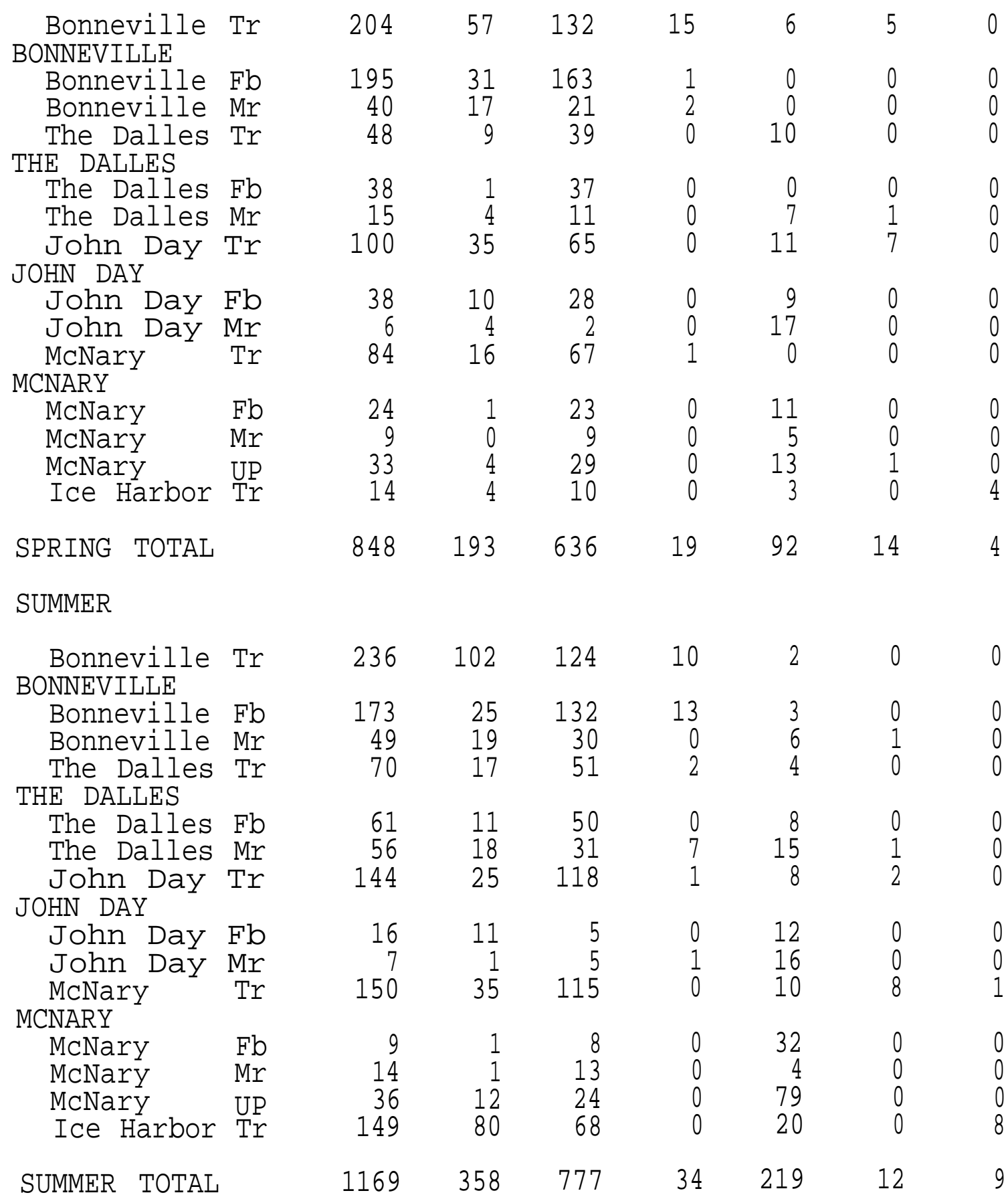



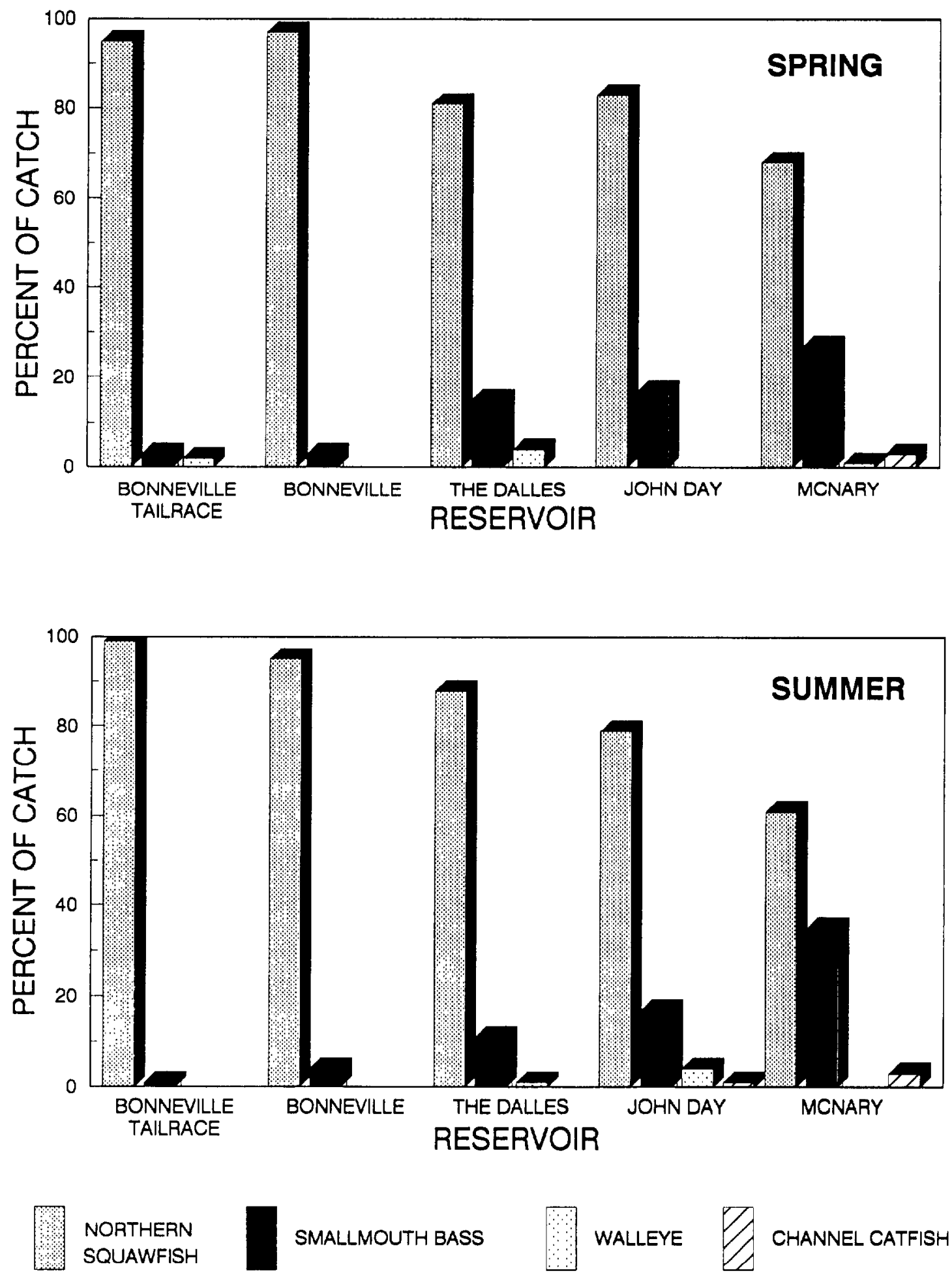

Figure 4. Percent of the predator catch per reservoir during 1990 spring and summer Consumption Indexing. Reservoirs represented are from dam to dam, including the BRZs. Bonneville Dam tailrace is included but is not considered a reservoir. 
the total catch increased (Figure 4). Of the 310 smallmouth bass collected, 30\% were captured at the upper McNary location, $14 \%$ in the McNary Dam forebay and $11 \%$ at the John Day mid-reservoir

\section{location.}

Walleyes were captured throughout the sampled reservoirs in low numbers. Most common occurrences were associated with dam tailraces but some fish were taken in mid-reservoir locations. No walleyes were taken in a dam forebay area.

Channel catfish were collected in low numbers (Figure 4). A total of 14 fish were collected during the entire sample season, 13 from Ice Harbor Dam tailrace.

Suckers (Catostomus ssp., primarily large-scale, c. macrocheilus, and bridgelip suckers, c. columbianus) were the most common non-target fish observed while electrofishing. Other species commonly observed during sampling included: carp

(Cyprinus carpio), peamouth (Mvlocheilus caurinus), chiselmouth (Acrocheilusalutaceus), and American shad (Alosa sanidissima). The highest diversity of species occurred at the upper McNary location where a total of 13 non-target species were identified in addition to target predators captured.

Adult salmon, steelhead and white sturgeon were

occassionally shocked during sampling. The sampling crew stopped electroshocking to allow these fish to recover or drift out of the current field. Incidentally shocked adult salmonids and white sturgeon were not netted or followed downriver, so no estimate of their mortality was possible.

Consumption Indexing

Analyses of the variability of northern squawfish data collected during 1983-86 in John Day Reservoir suggested that 1530 fish per day, or 30-60 fish per two-day period, would provide a reasonable sample for indexing consumption (Petersen et al. 1990). During 1990 sampling, we caught the minimum of 30 fish, during two days of effort, at 9 of 14 locations in the spring and 10 of 14 locations in the summer (Table 3). The 2-day upper target of 60 fish proved more difficult and was achieved on 10 of 
Table 3. Northern squawfish consumption indices (CI) at locations in the lower Columbia and Snake Rivers during 1990. Note that a single 0 means no juvenile salmonids were found in the predator guts while 0.0 means the estimate was less than 0.05 . CI is the consumption index for the original sample (N). Mean CI, standard deviation (SD), coefficient of variation (CV, $\%$ ) and quartiles are given for the 500 bootstrap samples. Tr=Tailrace, Fb=Forebay, Mr=mid-reservoir, Up=Upper reservoir.

\begin{tabular}{|c|c|c|c|c|c|c|c|c|}
\hline \multirow{3}{*}{\multicolumn{2}{|c|}{$\begin{array}{l}\text { RESERVOIR } \\
\text { Location }\end{array}$}} & \multirow{3}{*}{$\mathrm{N}$} & \multirow{3}{*}{ CI } & \multirow[b]{3}{*}{ Mean } & \multicolumn{4}{|c|}{ Boot strap summary } \\
\hline & & & & & \multirow[b]{2}{*}{ SD } & \multirow[b]{2}{*}{$\mathrm{CV}$} & \multicolumn{2}{|c|}{ Quartiles } \\
\hline & & & & & & & $2 \overline{5 \text { th }}$ & 75 th \\
\hline \multicolumn{9}{|l|}{ SPRING } \\
\hline $\begin{array}{l}\text { Bonneville } \\
\text { BONNEVILLE }\end{array}$ & $\operatorname{Tr}$ & 149 & 2.2 & 2.2 & 0.4 & 17 & 2.0 & 2.5 \\
\hline Bonneville & $\mathrm{Fb}$ & $\begin{array}{r}153 \\
20\end{array}$ & 0.6 & 0.6 & 0.2 & 32 & 0.5 & 0.7 \\
\hline $\begin{array}{l}\text { Bonneville } \\
\text { The Dalles }\end{array}$ & $\begin{array}{l}\mathrm{Mr} \\
\mathrm{Tr}\end{array}$ & 39 & $\begin{array}{l}0 \\
5\end{array}$ & 0 & 0 & & 0 & 0 \\
\hline \multicolumn{9}{|c|}{ THE DALLES } \\
\hline The Dalles & $\mathrm{Fb}$ & 38 & 0.8 & 0.8 & 0.2 & 28 & 0.7 & 0.9 \\
\hline The Dalles & $\mathrm{Mr}$ & 15 & 0 & 0 & & & & \\
\hline \multicolumn{6}{|l|}{ JOHN DAY } & 15 & 0.8 & 0.9 \\
\hline John Day & Fbo & 38 & 1.5 & 1.5 & 0.2 & 13 & 1.4 & 1.6 \\
\hline John Day & $\underset{\mathrm{T} m}{\mathrm{Mr}}$ & 6 & 0 & 0 & 0 & & 0 & 0 \\
\hline $\begin{array}{l}\text { McNary } \\
\text { MCNARY }\end{array}$ & & & & 2.2 & 0.2 & 10 & 2.1 & 2.4 \\
\hline McNary & $\mathrm{Fb}$ & 24 & 1.4 & 1.4 & 0.3 & 22 & 1.2 & 1.6 \\
\hline McNary & $\mathrm{Mr}$ & 9 & 0.2 & 0.1 & 0.1 & 75 & 0.0 & 0.2 \\
\hline McNary & UP & 33 & 1.5 & 1.7 & 0.7 & 44 & 1.2 & 2.1 \\
\hline Ice Harbor & $\operatorname{Tr}$ & 14 & 4.8 & 5.5 & 4.2 & 77 & 2.4 & 7.1 \\
\hline \multicolumn{9}{|l|}{ SUMMER } \\
\hline $\begin{array}{l}\text { Bonneville } \\
\text { BONNEVILLE }\end{array}$ & $\operatorname{Tr}$ & 154 & 3.9 & 3.8 & 1.0 & 25 & 3.1 & 4.5 \\
\hline Bonneville & $\mathrm{Fb}$ & 139 & 1.6 & 1.6 & 0.6 & 36 & 1.2 & 2.0 \\
\hline Bonneville & $\mathrm{Mr}$ & 42 & & 0 & & & & 0 \\
\hline The Dalles & $\operatorname{Tr}$ & 67 & 0.4 & 0.4 & 0.2 & 48 & 0.0 & 0.6 \\
\hline \multicolumn{9}{|c|}{ THE DALLES } \\
\hline The Dalles & $\mathrm{Fb}$ & 61 & 0.9 & 0.9 & 0.5 & 51 & 0.6 & 1.2 \\
\hline The Dalles & $\mathrm{Mr}$ & 51 & 0.1 & 0.1 & 0.1 & 98 & 0.0 & 0.2 \\
\hline \multicolumn{9}{|c|}{ JOHN DAY } \\
\hline John Day & $\mathrm{Fb}$ & 16 & 2.2 & 2.5 & 1.8 & 74 & 1.1 & 3.4 \\
\hline John Day & $\mathrm{Mr}$ & 7 & 0.9 & & 1.1 & 106 & 0.0 & 1.5 \\
\hline McNary & $\operatorname{Tr}$ & 75 & 7.5 & 7.5 & 1.3 & 17 & 6.7 & 8.4 \\
\hline \multicolumn{9}{|l|}{ MCNARY } \\
\hline McNary & $\begin{array}{ll}\mathrm{H} D \\
\mathrm{Mr}\end{array}$ & 13 & 2.3 & 2.4 & $1 \cdot 2$ & $\begin{array}{l}50 \\
59\end{array}$ & 1.6 & $\begin{array}{l}3.3 \\
2\end{array}$ \\
\hline $\begin{array}{l}\text { McNary } \\
\text { McNary }\end{array}$ & $\begin{array}{l}\mathrm{M} r \\
\mathrm{UP}\end{array}$ & 36 & $\begin{array}{l}1.6 \\
1.5\end{array}$ & $\begin{array}{l}1.1 \\
1.5\end{array}$ & $\begin{array}{l}1.0 \\
0.5\end{array}$ & $\begin{array}{l}59 \\
34\end{array}$ & 0.9 & 2.3 \\
\hline Ice Harbor & $\operatorname{Tr}$ & 112 & 0.5 & 0.6 & 0.3 & 62 & 0.3 & 0.7 \\
\hline
\end{tabular}


28 time-locations (Table 3).

Difficulty in meeting sampling targets at specific locations, especially mid-reservoir locations (Table 3), reduced the statistical power with which comparisons could be made since small-sample variation tended to be greater than variation in samples with many northern squawfish; for example, coefficients of variation were inversely related to sample size, in general (Table 3). To estimate the statistical power $(1.0$ minus Type II error; Type I error set to . 05) achievable when comparing cI's, we calculated the power for some hypothetical comparisons and averaged similar power estimates. cI's from mid-reservoir locations, which had the smallest samples and the greatest variability, were examined as a conservative example. Measured CI's from mid-reservoir locations $(\mathrm{N}=6)$ were compared to a hypothetical CI that was one-half the measured estimate (CI vs. CI/2; average power $=89 \%)$, and also to a hypothetical CI that was two times the measured CI (CI VS. $2 * C I$; average power $=97 \%$ ). Comparisons of cI's from tailrace and forebay locations had even higher power because the measured CI estimates from these locations had smaller relative standard deviations (CV's; Table 3) than the cI's from the mid-reservoir locations. These results indicate that locations can be ranked, with high confidence (power), by their relative consumption rates.

Consumption indices of northern squawfish ranged from zero at several locations to 7.5 in the McNary tailrace during summer sampling (Table 3). Northern squawfish collected from tailraces and forebays tended to have the highest CI values with a few exceptions. Mean CI's were always very close to the CI based upon the original fish sample, as expected. The coefficient of variation of northern squawfish CI means averaged 43\%, with a high value of $106 \%$ in John Day mid-reservoir when sample size was only 7 northern squawish (Table 3 ).

Compared to the spring period, northern squawfish CI's were higher during the summer in 10 of the 14 locations (Table 3). Forthese 10 locations, index values increased from spring to summer by an average of $1.5 \mathrm{CI}$ units. The only notable 
exceptions to higher summer consumption at a location occurred in The Dalles tailrace and Ice Harbor tailrace, which both had higher northern squawfish CI's in the spring. In The Dalles tailrace, the CI dropped from 1.5 in the spring to 0.4 during the summer sampling. The drop at the Ice Harbor tailrace was from 4.8 to 0.5, although a relatively small sample of fish $(\mathrm{N}=14)$ was collected during the spring.

During the spring period, northern squawfish taken from all tailrace areas had relatively high CI's (0.9 to 4.8) compared to fish from forebays and mid-reservoir locations (Table 3 ). Northern squawfish in forebays had moderately high CI's $(0.6$ to 1.5) and fish from mid-reservoir locations had CI's that were very low (0 to 0.2). Northern squawfish from the McNary upper location, within the Hanford reach, had a moderately high CI (1.5). During the summer, CI's of northern squawfish by location followed a similar pattern as observed in the spring (Table 3). Sample sizes in the mid-reservoir locations were generally low (Table 3). In the Bonneville mid-reservoir location, however, 39 and 42 northern squawfish were collected in spring and summer, respectively. None of these fish contained juvenile salmonid prey in their guts, resulting in CI estimates of zero (Table 3). Northern squawfish CI's for the BRZ's within tailraces and forebays are given in Table 4. During the spring, northern squawfish CI's were particularly high at the BRZ's of Bonneville Dam tailrace, McNary Dam tailrace and forebay, and the Ice Harbor Dam tailrace, although sample size was fairly small in the BRZ's of Ice Harbor Dam tailrace and the McNary Dam forebay (Table 4). During the summer, the northern squawfish collected from the BRZ's of tailraces of Bonneville, John Day and McNary dams had high CI's (4.6-11.2); in contrast, The Dalles and Ice Harbor tailrace BRZ's had summer CI's near zero (Table 4).

Consumption indices estimated for northern squawfish at the BRZ'S of dam tailraces and forebays were significantly higher than CI's estimated for northern squawfish from the adjacent nonBRZ area (Table 5). In the spring, CI's averaged only $0.7 \mathrm{CI}$ units greater in the BRZ's compared to outside. In the summer, 
Table 4. Consumption indices (CI) of northern sguawfish within dam BRZ's in the lower Columbia and Snake Rivers during 1990. See Table 3 for explanation of columns.

\begin{tabular}{|c|c|c|c|c|c|c|c|c|}
\hline \multirow{3}{*}{\multicolumn{2}{|c|}{$\begin{array}{l}\text { RESERVOIR } \\
\text { Location } \\
\text { (BRZ only) }\end{array}$}} & \multirow{3}{*}{$\mathrm{N}$} & \multirow{3}{*}{$C I$} & \multicolumn{5}{|c|}{ Bootstrap Summary } \\
\hline & & & & & & & & tiles \\
\hline & & & & Mean & SD & $\mathrm{CV}$ & $2 \overline{5 t h}$ & 75 th \\
\hline \multicolumn{9}{|l|}{ SPRING } \\
\hline Bonneville & $\operatorname{Tr}$ & 89 & 2.5 & 2.5 & 0.3 & 13 & 2.3 & 2.7 \\
\hline $\begin{array}{l}\text { BONNEVILLE } \\
\text { Bonnevile }\end{array}$ & $\mathrm{Fb}$ & 102 & 0.8 & 0.8 & 0.2 & 26 & 0.7 & 1.0 \\
\hline The Dalles & $\operatorname{Tr}$ & 41 & 0.2 & 0.2 & 0.1 & 55 & 0.2 & 0.3 \\
\hline $\begin{array}{l}\text { THE DALLES } \\
\text { The Dalles }\end{array}$ & & & & & & & & \\
\hline $\begin{array}{l}\text { The Dalles } \\
\text { John Day }\end{array}$ & $\begin{array}{ll}\text { EDb } \\
T r\end{array}$ & 20 & 1.0 & $1 \cdot \frac{1}{0}$ & 0.8 & 71 & 0.5 & 1.4 \\
\hline JOHN DAY & $\perp \perp$ & & & & & & & \\
\hline John Day & Fb & 34 & 1.6 & 1.7 & 0.9 & 50 & 1.0 & 2.2 \\
\hline McNary & $\operatorname{Tr}$ & 60 & 2.4 & 2.4 & 0.2 & 9 & 2.2 & 2.6 \\
\hline \multicolumn{9}{|l|}{ MCNARY } \\
\hline McNary & $\mathrm{Fb}$ & 17 & 7.8 & 8.5 & 5.5 & 65 & 4.4 & 11.5 \\
\hline Ice Harbor & $\operatorname{Tr}$ & 14 & 4.8 & 5.5 & 4.2 & 77 & 2.4 & 7.1 \\
\hline \multicolumn{9}{|l|}{ SUMMER } \\
\hline $\begin{array}{l}\text { Bonneville } \\
\text { B }\end{array}$ & $\operatorname{Tr}$ & 109 & 4.6 & 4.6 & 0.9 & 20 & 4.0 & 5.2 \\
\hline $\begin{array}{l}\text { BONNEVILLE } \\
\text { Bonnevile }\end{array}$ & $\mathrm{Fh}$ & 89 & 2.2 & 22 & 0.6 & 29 & 18 & 27 \\
\hline The Dalles & $\operatorname{Tr}$ & 63 & 0.0 & 0.0 & 0.0 & 61 & 0.0 & 0.1 \\
\hline \multicolumn{9}{|l|}{ THE DALLES } \\
\hline The Dalles & $\mathrm{Fb}$ & 25 & 2.8 & 2.8 & 1.1 & 39 & 1.2 & 3.6 \\
\hline $\begin{array}{l}\text { John Day } \\
\text { JOHN DAY }\end{array}$ & $\operatorname{Tr}$ & 50 & 6.3 & 6.3 & 0.7 & 11 & 5.8 & 6.8 \\
\hline John Day & $\mathrm{Fb}$ & 11 & 0.0 & 0.0 & 0.0 & 114 & 0.0 & 0.0 \\
\hline McNary & $\operatorname{Tr}$ & 50 & 11.2 & 11.2 & 1.0 & 9 & 10.5 & 12.0 \\
\hline \multicolumn{9}{|l|}{ MCNARY } \\
\hline $\begin{array}{l}\text { McNary } \\
\text { Ice Harbor }\end{array}$ & $\begin{array}{l}\text { Fb } \\
\text { Tr }\end{array}$ & $\begin{array}{r}8 \\
79\end{array}$ & $\begin{array}{l}0.0 \\
0.0\end{array}$ & $\begin{array}{l}0.1 \\
0.0\end{array}$ & $\begin{array}{l}0.1 \\
0.0\end{array}$ & $\begin{array}{l}78 \\
88\end{array}$ & $\begin{array}{l}0.0 \\
0.0\end{array}$ & $\begin{array}{l}0.1 \\
0.0\end{array}$ \\
\hline & & & & & & & & \\
\hline
\end{tabular}


Table 5. Comparison of mean northern squawfish CI's within the boat restricted zone (BRZ) versus outside the BRZ in selected dam tailraces ( $\operatorname{Tr})$ and forebays (Fb). Only locations where sample size (N) was at least 15 northern squawfish were compared. $P$ is the probability that means were equal using a Mann-Whitney U test upon the 500 bootstrapped estimates for each mean.

\begin{tabular}{|c|c|c|c|c|c|c|c|c|}
\hline \multirow[t]{2}{*}{$\begin{array}{l}\text { RESERVOIR } \\
\text { Location }\end{array}$} & & \multicolumn{3}{|c|}{ BRZ } & \multicolumn{3}{|c|}{ Outside BRZ } & \multirow[t]{2}{*}{$\mathrm{P}$} \\
\hline & & Mean & SD & $\mathrm{N}$ & Mean & $\mathrm{SD}$ & $\mathrm{N}$ & \\
\hline \multicolumn{9}{|l|}{ SPRING } \\
\hline $\begin{array}{l}\text { Bonneville } \\
\text { BONNEVILLE }\end{array}$ & $\operatorname{Tr}$ & 2.5 & 0.3 & 89 & 1.8 & 0.5 & 60 & $x .001$ \\
\hline $\begin{array}{l}\text { Bonneville } \\
\text { THE DALLES }\end{array}$ & $\mathrm{Fb}$ & 0.8 & 0.2 & 102 & 0.1 & 0.1 & 51 & $<.001$ \\
\hline $\begin{array}{l}\text { John Day } \\
\text { JOHN DAY }\end{array}$ & $\operatorname{Tr}$ & 0.9 & 0.2 & 50 & 0.7 & 0.2 & 27 & $<.001$ \\
\hline McNary & $\operatorname{Tr}$ & 2.4 & 0.2 & 60 & 1.6 & 0.4 & 17 & $x .001$ \\
\hline \multicolumn{9}{|l|}{ SUMQMER } \\
\hline $\begin{array}{l}\text { Bonneville } \\
\text { BONNEVILLE }\end{array}$ & $\operatorname{Tr}$ & 4.6 & 0.8 & 109 & 0.3 & 0.1 & 45 & $<.001$ \\
\hline $\begin{array}{l}\text { Bonneville } \\
\text { THE DALLES }\end{array}$ & $\mathrm{Fb}$ & 2.2 & 0.4 & 89 & 0 & 0 & 50 & $\mathrm{x} .001$ \\
\hline $\begin{array}{l}\text { The Dalles } \\
\text { John Day } \\
\text { JOHN DAY }\end{array}$ & $\begin{array}{l}\mathrm{Fb} \\
\mathrm{Tr}\end{array}$ & $\begin{array}{l}2.8 \\
6.3\end{array}$ & $\begin{array}{l}1.2 \\
0.5\end{array}$ & $\begin{array}{l}25 \\
50\end{array}$ & $\begin{array}{r}0.2 \\
0\end{array}$ & $\begin{array}{r}0.0 \\
0\end{array}$ & $\begin{array}{l}36 \\
46\end{array}$ & $\begin{array}{l}<.001 \\
<.001\end{array}$ \\
\hline $\begin{array}{l}\text { MCNary } \\
\text { MCNARY }\end{array}$ & $\operatorname{Tr}$ & 11.2 & 1.0 & 50 & 2.6 & 2.1 & 25 & $<.001$ \\
\hline Ice Harbor & $\operatorname{Tr}{ }^{\prime}$ & 0.0 & 0.0 & 79 & 0 & 0 & 33 & $<.001$ \\
\hline
\end{tabular}

'Mean CI within the BRZ was 2.453-3 (SD = 2.153-3); rounding causes 0.0 for Ice Harbor Tr BRZ. 
however, northern squawfish consumption differences between adjacent areas were much greater, averaging $4.0 \mathrm{CI}$ units. The most dramatic difference occurred in the John Day and McNary tailraces where BRZ consumption indices were 6.3 and 8.7 CI units higher, respectively, than outside the BRZ (Table 5). Ice Harbor tailrace BRZ and non-BRZ northern squawfish consumption rates were very low in the summer, although the CI in the BRZ was still significantly higher than the CI measured outside of the BRZ $(P<$ .001; Table 5). Northern squawfish CI's from both the tailrace and forebay BRZ's were higher than adjacent zones (Table 5). Higher northern squawfish CI's within BRZ's occurred in all reservoirs where adequate tests could be made (Table 5).

Our original intent was to estimate reservoir-wide consumption indices by combining samples from all locations in a reservoir for a given time period. Several results suggested that this strategy was not the best way to accurately index consumption in a reservoir. First, catches in different parts of a reservoir were usually very different due to the difficulty of collecting northern squawfish at mid-reservoir locations (Table 2) * Unbalanced catches of predators would bias reservoir-wide CI's toward those locations where the greatest number of predators were caught - usually the BRZ's within tailraces and forebays. Secondly, comparisons of northern squawfish CI's in the BRZ's versus the CI's in adjacent, non-BRZ areas of the tailraces and forebays (see section above: Table 5) indicated that areas very near dams (BRZ's) had especially high predation rates. Tailrace and forebay areas outside the BRZ's usually had estimates that were more similar to mid-reservoir estimates than to the adjacent BRZ (Tables 3 and 5). Finally, low catches and many empty northern squawfish guts at several mid-reservoir locations caused their CI's to be zero. Although juvenile salmonid consumption could be zero or very low in some midreservoirs, complete lack of northern squawfish predation upon salmonids (zero CI) seems unlikely based upon earlier data from John Day Reservoir (Poe et al. 1988; Vigg et al. 1988). For the above reasons, and to increase sample size, 
Table 6. Reservoir-wide (excluding BRZ's at dams) CI's of northern squawfish during 1990 sampling in the lower Columbia and Snake Rivers. See Table 3 for explanation of columns.

\begin{tabular}{|c|c|c|c|c|c|c|c|}
\hline \multirow{3}{*}{$\begin{array}{c}\text { RESERVOIR } \\
\text { (excluding } \\
\text { BRZ's ) }\end{array}$} & \multirow{3}{*}{$\mathrm{N}$} & \multirow{3}{*}{ CI } & \multicolumn{5}{|c|}{ Bootstrap Summary } \\
\hline & & & \multirow[b]{2}{*}{ Mean } & \multirow[b]{2}{*}{$\mathrm{SD}$} & \multirow[b]{2}{*}{$\mathrm{CV}$} & \multicolumn{2}{|c|}{ Quartiles } \\
\hline & & & & & & $25 t h$ & $75 t h$ \\
\hline \multicolumn{8}{|l|}{ SPRING } \\
\hline $\begin{array}{l}\text { BONNEVILLE } \\
\text { THE DALLES } \\
\text { JOHN DAY } \\
\text { MCNARY }\end{array}$ & $\begin{array}{l}97 \\
58 \\
27 \\
49\end{array}$ & $\begin{array}{l}0.0 \\
0.1 \\
0.5 \\
0.2\end{array}$ & $\begin{array}{l}0.0 \\
0.1 \\
0.6 \\
0.2\end{array}$ & $\begin{array}{l}0.0 \\
0.0 \\
0.4 \\
0.1\end{array}$ & $\begin{array}{r}141 \\
74 \\
73 \\
69\end{array}$ & $\begin{array}{l}0.0 \\
0.0 \\
0.3 \\
0.1\end{array}$ & $\begin{array}{l}0.0 \\
0.1 \\
0.8 \\
0.2\end{array}$ \\
\hline \multicolumn{8}{|l|}{ SUMMER } \\
\hline $\begin{array}{l}\text { BONNEVILLE } \\
\text { THE DALLES } \\
\text { JOHN DAY } \\
\text { MCNARY }\end{array}$ & $\begin{array}{r}96 \\
133 \\
37 \\
83\end{array}$ & $\begin{array}{l}0 \\
0.0 \\
0.2 \\
0.1\end{array}$ & $\begin{array}{l}0 \\
0.0 \\
0.2 \\
0.1\end{array}$ & $\begin{array}{l}0 \\
0.0 \\
0.1 \\
0.1\end{array}$ & $\begin{array}{r}- \\
106 \\
78 \\
54\end{array}$ & $\begin{array}{l}0 \\
0.0 \\
0.1 \\
0.1\end{array}$ & $\begin{array}{l}0 \\
0.0 \\
0.2 \\
0.2\end{array}$ \\
\hline
\end{tabular}


"reservoir-wide" consumption was estimated by combining all samples collected between two dams, except those samples from the forebav and tailrace BRZ's (see Figure 2). Northern squawfish reservoir-wide CI's were quite low $(<1.0)$ in spring and summer (Table 6). In the spring period, the rank order of northern squawfish CI's, from lowest to highest, was Bonneville, The Dalles, McNary and John Day reservoirs. The inter-quartile ranges of the four reservoirs did not overlap (Table 6), suggesting northern squawfish consumption rates may differ among some reservoirs. In the summer, mean CI's of northern squawfish in Bonneville and The Dalles reservoirs were near zero. Out of 229 gut samples examined from these reservoirs in the summer, only 2 salmonids were recovered. The CI's for northern squawfish from John Day and McNary reservoirs were higher than CI's of northern squawfish in Bonneville and The Dalles reservoirs (Table 6).

Diet Summary of Northern Squawfish

Tables 7-12 summarize diet information. Diet summaries by location (tailrace, mid-reservoir and forebay) are in Tables 7 and 8; Tables 9 and 10 have information for BRZ's only, and Tables 11 and 12 summarize reservoir-wide (excluding BRZ's) northern squawish gut content data.

In the laboratory, 1,598 northern squawfish gut samples were analyzed. The overall diet of squawfish was dominated by fish and crustaceans (45\% and 37\%, respectively: Table 7). Fish were the most important prey item for northern squawfish from the BRZ areas (Table 9). In contrast, crustaceans were the dominant prey item of northern squawfish in reservoir-wide areas, except in the John Day reservoir (Table 11). Crayfish made up the greatest portion of crustacean weight. Amphipods were also present, especially in small northern squawfish $(<350 \mathrm{~mm} F L)$. During the summer sampling period, insects and plants also became important inthe reservoir area ( $8.3 \%$ and $8.9 \%$, respectively).

Using diagnostic bone counts, 939 juvenile salmonids were found in 435 northern squawfish; 18 other northern squawfish 
Table 7. Gut content of northern squauf i sh at I ocati ons in the I ouer Col unbi a and Snake Ri vers duri ng 1990 . Gut contents $(\%)$ are the nean of percentages of i ndi vi dual nort hern squauf i sh that had non- empty guts. Crust. = crustacean; Mol I. = nol I usk. Tr=Tai I race, $\mathbf{F b}=$ For ebay, $\mathbf{M}=\mathbf{M} \mathbf{d}$ - reservoi $\mathbf{r}$, and $\mathbf{U}=U$ pper reservoi $r$.

RESERVOIR Locati on

Mean
N gut ut. empty

(9) guts

GT CONIENTS $(\%$

Fi sh Crust. Mol I. Insect PI ant Other

\section{SPR NG}

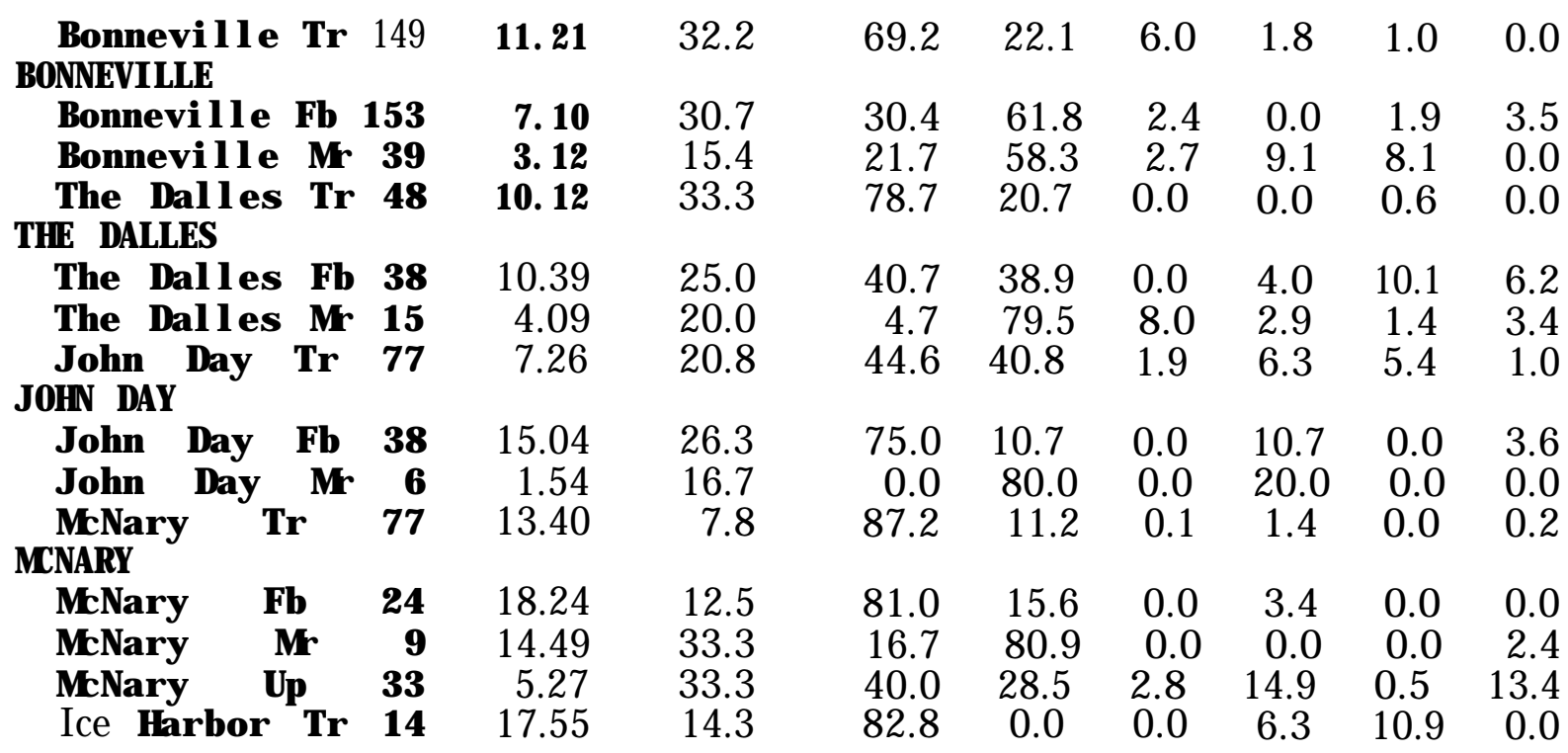

SUMMER

\begin{tabular}{|c|c|c|c|c|c|c|c|c|c|}
\hline $\begin{array}{l}\text { Bonnevi I I e Tr } \\
\text { BONNEY LLE }\end{array}$ & 155 & 8.12 & 45.2 & 53.4 & 35.3 & 3.0 & 0.0 & 4.4 & 3.9 \\
\hline Bonnevi I le Fb & 139 & 10.37 & 41.7 & 25.6 & 48.3 & 2.4 & 9.2 & 5.8 & 8.9 \\
\hline Bonnevi I I e & 42 & 4.32 & 16.7 & 7.4 & 59.8 & 3.3 & 14.4 & 12.7 & 2.4 \\
\hline $\begin{array}{l}\text { The Dal I es Tr } \\
\text { THE DALLES }\end{array}$ & 67 & 7.67 & 62.7 & 24.2 & 41.3 & 3.4 & 3.3 & 17.0 & 10.7 \\
\hline The Dal I es Fk & 61 & 4.56 & 42.6 & 11.2 & 63.9 & 0.8 & 8.7 & 12.2 & 3.2 \\
\hline The Dal I es M & 51 & 2.65 & 23.5 & 4.2 & 43.1 & 0.0 & 33.9 & 9.8 & 8.8 \\
\hline $\begin{array}{l}\text { John Day } \\
\text { J OHN DAY }\end{array}$ & 96 & 4.37 & 36.5 & 57.0 & 29.9 & 4.6 & 0.1 & 5.0 & 3.4 \\
\hline John Day & 16 & 1.30 & 68.8 & 40.0 & 20.0 & 0.0 & 40.0 & 0.0 & 0.0 \\
\hline John Day M & 7 & 4.00 & 42.9 & 21.7 & 73.1 & 0.0 & 2.7 & 2.5 & 0.0 \\
\hline MeNary Tr & 75 & 6.26 & 13.3 & 75.9 & 9.9 & 2.6 & 1.8 & 2.3 & 7.6 \\
\hline MeNary & 9 & 3.86 & 33.3 & 49.3 & 0.0 & 0.0 & 50.7 & 0.0 & 0.0 \\
\hline MeNary & 13 & 6.90 & 7.7 & 24.7 & 66.9 & 0.0 & 0.0 & 0.0 & 8.4 \\
\hline MtNary & 36 & 8.45 & 11.1 & 21.0 & 45.9 & 1.3 & 5.7 & 20.0 & 6.1 \\
\hline Ice Harbor Tr & 112 & 2.60 & 69.6 & 17.6 & 26.8 & 3.9 & 13.4 & 26.8 & 11.4 \\
\hline
\end{tabular}


Table 8. Prey fi sh consumed by northern squauf ish (SQF) at I ocati ons in the I ower Col unbi a and Snake Ri vers duri ng 1990. FL fork I ength; Mean Fi sh W. = nean prey fish mass ( $g$ ) per predator; \% snolts = percent of the total number of

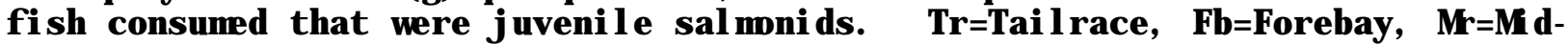
reservoi $r$, Up=Upper reservoi $r$.

\begin{tabular}{|c|c|c|c|c|c|c|c|c|c|}
\hline \multirow{2}{*}{$\begin{array}{l}\text { RESERVa } R \\
\text { Locati on }\end{array}$} & & \multicolumn{2}{|c|}{ PREDATORS } & \multicolumn{6}{|c|}{ PREY FI SH CONSUMED } \\
\hline & & $\mathbf{N}$ & $\begin{array}{l}\text { Mean } \\
\text { FL ( } \mathbf{m})\end{array}$ & $\begin{array}{l}\text { Mean } \\
\text { Fi sh } \\
\text { ut. } \\
\text { (g) }\end{array}$ & $\begin{array}{l}\text { Total } \\
\# \\
\text { Smolts }\end{array}$ & $\begin{array}{c}\# \\
\text { Snol t s } \\
\text { Per } \\
\text { SQF }\end{array}$ & $\begin{array}{c} \\
\% \\
\text { Snol ts }\end{array}$ & $\begin{array}{c}\text { Total } \\
\# \\
\text { Other } \\
\text { Fi sh }\end{array}$ & $\begin{array}{c}\text { \% } \\
\text { Other } \\
\text { Fi sh }\end{array}$ \\
\hline \multicolumn{10}{|l|}{ SPRING } \\
\hline $\begin{array}{l}\text { Bonnevi I l e } \\
\text { BONNEY LLE }\end{array}$ & $\operatorname{Tr}$ & 149 & 392.7 & 6.99 & 161 & 1.1 & 95.8 & 7 & 4.2 \\
\hline $\begin{array}{l}\text { Bonnevi I l e } \\
\text { Bonnevi I l e } \\
\text { The Dal l es } \\
\text { THE DALLES }\end{array}$ & $\begin{array}{l}\mathbf{F b} \\
\mathbf{M r} \\
\mathbf{T r}\end{array}$ & $\begin{array}{r}153 \\
39 \\
48\end{array}$ & $\begin{array}{l}391.5 \\
344.9 \\
426.6\end{array}$ & $\begin{array}{r}2.45 \\
0.89 \\
6.4\end{array}$ & $\begin{array}{r}33 \\
0 \\
32\end{array}$ & $\begin{array}{l}0.2 \\
0.0 \\
0.7\end{array}$ & $\begin{array}{r}80.5 \\
0.0 \\
91.4\end{array}$ & $\begin{array}{r}8 \\
11 \\
3\end{array}$ & $\begin{array}{r}19.5 \\
100.0 \\
8.6\end{array}$ \\
\hline $\begin{array}{l}\text { The Dall es } \\
\text { The Dal l es } \\
\text { J ohn Day } \\
\text { J OHN DAY }\end{array}$ & $\begin{array}{l}\mathbf{F b} \\
\mathbf{M r} \\
\mathbf{T r}\end{array}$ & $\begin{array}{l}38 \\
15 \\
77\end{array}$ & $\begin{array}{c}423.6 \\
346.3 \\
391.6\end{array}$ & $\begin{array}{l}4.81 \\
0.16 \\
5.29\end{array}$ & $\begin{array}{r}15 \\
0 \\
32\end{array}$ & $\begin{array}{l}0.4 \\
0.0 \\
0.4\end{array}$ & $\begin{array}{r}100.0 \\
0.0 \\
86.5\end{array}$ & $\begin{array}{l}1 \\
5 \\
0\end{array}$ & $\begin{array}{r}0.0 \\
100.0 \\
13.5\end{array}$ \\
\hline $\begin{array}{l}\text { John Day } \\
\text { John Day } \\
\text { MENary } \\
\text { MCNARY }\end{array}$ & $\begin{array}{l}\mathbf{F b} \\
\mathbf{M r} \\
\mathrm{Tr}\end{array}$ & $\begin{array}{r}38 \\
6 \\
77\end{array}$ & $\begin{array}{l}418.6 \\
351.0 \\
417.2\end{array}$ & $\begin{array}{r}10.77 \\
0 \\
11.83\end{array}$ & $\begin{array}{r}34 \\
0 \\
124\end{array}$ & $\begin{array}{l}0.9 \\
0.0 \\
1.6\end{array}$ & $\begin{array}{r}100.0 \\
- \\
98.4\end{array}$ & 0 & $\begin{array}{r}0.0 \\
- \\
1.6\end{array}$ \\
\hline $\begin{array}{l}\text { MeNary } \\
\text { MeNary } \\
\text { MENary } \\
\text { Ice Harbor }\end{array}$ & $\begin{array}{l}\mathbf{F b} \\
\mathbf{M r} \\
\text { Up } \\
\text { Tr }\end{array}$ & $\begin{array}{r}24 \\
9 \\
33 \\
14\end{array}$ & $\begin{array}{r}437.4 \\
429.6 \\
398.1 \\
446.1\end{array}$ & $\begin{array}{r}15.63 \\
5.89 \\
2.66 \\
13.58\end{array}$ & $\begin{array}{r}29 \\
1 \\
21 \\
26\end{array}$ & $\begin{array}{l}1.2 \\
0.1 \\
0.6 \\
1.9\end{array}$ & $\begin{array}{r}93.5 \\
100.0 \\
95.5 \\
96.3\end{array}$ & $\begin{array}{l}2 \\
0 \\
1 \\
1\end{array}$ & $\begin{array}{l}6.5 \\
0.0 \\
4.5 \\
3.7\end{array}$ \\
\hline \multicolumn{10}{|l|}{ SUMMER } \\
\hline $\begin{array}{l}\text { Bonnevi I I e } \\
\text { BONNEV LLE }\end{array}$ & Tr & 155 & 372.0 & 3.97 & 123 & 0.8 & 96.1 & 5 & 3.9 \\
\hline $\begin{array}{l}\text { Bonnevi I l e } \\
\text { Bonnevi I l e } \\
\text { The Dal l es } \\
\text { THE DALLES }\end{array}$ & $\begin{array}{l}\mathbf{F b} \\
\mathbf{M r} \\
\mathrm{Tr}\end{array}$ & $\begin{array}{r}139 \\
42 \\
67\end{array}$ & $\begin{array}{r}369.9 \\
351.9 \\
403.7\end{array}$ & $\begin{array}{l}3.28 \\
0.27 \\
1.45\end{array}$ & $\begin{array}{r}49 \\
0 \\
6\end{array}$ & $\begin{array}{l}0.4 \\
0.0 \\
0.1\end{array}$ & $\begin{array}{r}86.0 \\
0.0 \\
75.0\end{array}$ & $\begin{array}{l}8 \\
5 \\
2 \\
2\end{array}$ & $\begin{array}{r}14.0 \\
100.0 \\
25.0\end{array}$ \\
\hline $\begin{array}{l}\text { The Dal les } \\
\text { The Dal l es } \\
\text { J ohn Day } \\
\text { J OHN DAY }\end{array}$ & $\begin{array}{l}\mathbf{F b} \\
\mathbf{M r} \\
\mathrm{Tr}\end{array}$ & $\begin{array}{l}\mathbf{6 1} \\
\mathbf{5 1} \\
96\end{array}$ & $\begin{array}{c}374.6 \\
346.2 \\
397.1\end{array}$ & $\begin{array}{r}0.56 \\
0.17 \\
2.4\end{array}$ & 6: & $\begin{array}{l}0.1 \\
0.0 \\
0.7\end{array}$ & $\begin{array}{r}81.8 \\
100.0 \\
100.0\end{array}$ & $\begin{array}{l}0 \\
1\end{array}$ & $\begin{array}{r}18.2 \\
0.0 \\
0.0\end{array}$ \\
\hline $\begin{array}{l}\text { John Day } \\
\text { John Day } \\
\text { MENary } \\
\text { MCNARY }\end{array}$ & $\begin{array}{l}\mathbf{F b} \\
\mathbf{M r} \\
\mathbf{T r}\end{array}$ & $\begin{array}{r}16 \\
7 \\
75\end{array}$ & $\begin{array}{r}399.5 \\
337.6 \\
406.8\end{array}$ & $\begin{array}{l}0.08 \\
0.24 \\
3.26\end{array}$ & $\begin{array}{r}2 \\
1 \\
136\end{array}$ & $\begin{array}{l}0.1 \\
0.1 \\
1.8\end{array}$ & $\begin{array}{r}66.7 \\
100.0 \\
97.1\end{array}$ & 0 & $\begin{array}{r}33003 \\
20 \% \\
2.9\end{array}$ \\
\hline $\begin{array}{l}\text { MeNary } \\
\text { MtNary } \\
\text { MtNary } \\
\text { Ice Harbor }\end{array}$ & $\begin{array}{l}\mathbf{F b} \\
\mathbf{M r} \\
\text { Up } \\
\text { Tr }\end{array}$ & $\begin{array}{r}9 \\
13 \\
36 \\
112\end{array}$ & $\begin{array}{l}381.6 \\
425.7 \\
373.3 \\
403.5\end{array}$ & $\begin{array}{l}1.27 \\
1.01 \\
1.29 \\
0.15\end{array}$ & $\begin{array}{c}4 \\
7 \\
22 \\
6\end{array}$ & $\begin{array}{l}0.4 \\
0.5 \\
0.7 \\
0.1\end{array}$ & $\begin{array}{r}100.0 \\
70.0 \\
92.9 \\
100.0\end{array}$ & $\begin{array}{l}0 \\
3 \\
2 \\
0\end{array}$ & $\begin{array}{r}0.0 \\
30.0 \\
7.1 \\
0.0\end{array}$ \\
\hline
\end{tabular}


Tabl e 9. Di et sumary of northern squauf i sh wi thi $n$ dam BRZ' s i $n$ the I ower Col unbi a and Snake Ri vers during 1990. See Table 7 for expl anation of col ums.

\begin{tabular}{|c|c|c|c|c|c|c|c|c|c|c|}
\hline \multirow{2}{*}{$\begin{array}{l}\text { KESEKVOIR } \\
\text { Locat i on } \\
\text { ( i n BRZ) }\end{array}$} & \multirow{2}{*}{\multicolumn{3}{|c|}{$\begin{array}{l}\text { Mean } \\
\text { N gut ut } \\
\text { (9) }\end{array}$}} & \multirow{2}{*}{$\begin{array}{l}\quad \% \\
\text { empt y } \\
\text { guts }\end{array}$} & \multicolumn{6}{|c|}{ GT CONTENTS ( $\%$} \\
\hline & & & & & Fi sh & Crust. & Mbl I. & I nsect & PI ant & Ot her \\
\hline \multicolumn{11}{|l|}{ SPRI NG } \\
\hline $\begin{array}{l}\text { Bonnevi I I e } \\
\text { BONNEY LLE }\end{array}$ & $\operatorname{Tr}$ & 89 & 16. 28 & 30.3 & 88.5 & 3.7 & 6.2 & 1.6 & 0.0 & 0.0 \\
\hline $\begin{array}{l}\text { Bonnevi I l e } \\
\text { The Dal I es } \\
\text { THE DALLES }\end{array}$ & $\begin{array}{l}\mathbf{F b} \\
\mathrm{Tr}\end{array}$ & $\begin{array}{r}102 \\
41\end{array}$ & $\begin{array}{l}7.79 \\
6.71\end{array}$ & $\begin{array}{l}35.3 \\
39.0\end{array}$ & $\begin{array}{l}43.4 \\
88.0\end{array}$ & $\begin{array}{l}48.9 \\
12.0\end{array}$ & $\begin{array}{l}3.5 \\
0.0\end{array}$ & $\begin{array}{l}0.0 \\
0.0\end{array}$ & $\begin{array}{l}1.5 \\
0.0\end{array}$ & $\begin{array}{l}2.6 \\
0.0\end{array}$ \\
\hline $\begin{array}{l}\text { The Dal l es } \\
\text { John Day } \\
\text { J OHN DAY }\end{array}$ & $\begin{array}{l}\mathrm{Fb} \\
\mathrm{Tr}\end{array}$ & $\begin{array}{l}21 \\
50\end{array}$ & $\begin{array}{r}13.23 \\
8.08\end{array}$ & $\begin{array}{l}28.6 \\
18.0\end{array}$ & $\begin{array}{l}66.7 \\
46.6\end{array}$ & $\begin{array}{l}26.7 \\
41.2\end{array}$ & $\begin{array}{l}0.5 \\
0.0\end{array}$ & $\ddot{7} .7$ & $\begin{array}{l}0.0 \\
3.0\end{array}$ & $\ddot{1.4}$ \\
\hline $\begin{array}{l}\text { John Day } \\
\text { MENary } \\
\text { MCNARY }\end{array}$ & $\begin{array}{l}\mathrm{Fb} \\
\mathrm{Tr}\end{array}$ & $\begin{array}{l}34 \\
60\end{array}$ & $\begin{array}{r}15.99 \\
13.4\end{array}$ & $\begin{array}{r}23.5 \\
6.7\end{array}$ & $\begin{array}{l}76.9 \\
91.0\end{array}$ & $\begin{array}{l}7.7 \\
8.8\end{array}$ & 0.0 & 10.6 & $\begin{array}{l}0.0 \\
0.0\end{array}$ & $\begin{array}{l}3.8 \\
0.2\end{array}$ \\
\hline $\begin{array}{l}\text { MtNary } \\
\text { Ice Har bor }\end{array}$ & $\begin{array}{l}\mathbf{F b} \\
\mathrm{Tr}\end{array}$ & $\begin{array}{l}17 \\
14\end{array}$ & $\begin{array}{r}23.3 \\
17.55\end{array}$ & $\begin{array}{r}5.9 \\
14.3\end{array}$ & $\begin{array}{l}93.8 \\
82.8\end{array}$ & $\begin{array}{l}6.3 \\
0.0\end{array}$ & $\begin{array}{l}0.0 \\
0.0\end{array}$ & $\begin{array}{l}0.0 \\
6.3\end{array}$ & $\begin{array}{r}0.0 \\
10.9\end{array}$ & $\begin{array}{l}0.0 \\
0.0\end{array}$ \\
\hline
\end{tabular}

\section{SUMMER}

\begin{tabular}{|c|c|c|c|c|c|c|c|c|c|c|}
\hline $\begin{array}{l}\text { Bonnevi I I e } \\
\text { BONNEY LLE }\end{array}$ & Tr & 109 & 9.37 & 33.9 & 60.2 & 29.8 & 2.1 & 0.0 & 4.3 & 3.6 \\
\hline Bonnevi I l e & $\mathbf{F b}$ & 89 & 14. 52 & 43. 8 & 39.0 & 40.5 & 0.0 & & 5.8 & 10.7 \\
\hline $\begin{array}{l}\text { The Dal I es } \\
\text { HE DALLES }\end{array}$ & Tr & 63 & 7.83 & 66. 7 & 28.9 & 37.4 & $\begin{array}{l}0.0 \\
0.0\end{array}$ & 4.0 & 20.3 & \\
\hline $\begin{array}{l}\text { The Dal I es } \\
\text { J ohn Day } \\
\text { OHN DAY }\end{array}$ & $\begin{array}{l}\mathbf{F b} \\
\mathrm{Tr}\end{array}$ & $\begin{array}{l}25 \\
50\end{array}$ & $\begin{array}{l}4.96 \\
5.89\end{array}$ & $\begin{array}{l}\text { 68. } 0 \\
24.0\end{array}$ & $\begin{array}{l}49.1 \\
91.6\end{array}$ & $\begin{array}{r}37.5 \\
2.6\end{array}$ & 0.4 & 10.2 & $\begin{array}{l}0.1 \\
5.3\end{array}$ & \\
\hline $\begin{array}{l}\text { John Day } \\
\text { MENbry } \\
\text { CNARY }\end{array}$ & $\begin{array}{l}\mathbf{F b} \\
\mathbf{T r}\end{array}$ & $\begin{array}{l}11 \\
50\end{array}$ & $\begin{array}{l}1.59 \\
4.92\end{array}$ & $\begin{array}{l}63.6 \\
22.0\end{array}$ & $\begin{array}{l}50.0 \\
89.7\end{array}$ & $\begin{array}{r}25.0 \\
0.0\end{array}$ & $\begin{array}{l}0.0 \\
0.0\end{array}$ & $\begin{array}{r}25.0 \\
0.0\end{array}$ & $\begin{array}{l}0.0 \\
2.6\end{array}$ & \\
\hline $\begin{array}{l}\text { MeNary } \\
\text { Ice Har bor }\end{array}$ & $\begin{array}{l}\mathrm{Fb} \\
\mathrm{Tr}\end{array}$ & $\begin{array}{r}8 \\
79\end{array}$ & $\begin{array}{l}3.86 \\
2.88\end{array}$ & 25.0 & $\begin{array}{l}49.3 \\
199\end{array}$ & 0.0 & $\begin{array}{l}0.0 \\
4.0\end{array}$ & $\begin{array}{l}50.7 \\
11.6\end{array}$ & $\begin{array}{r}0.0 \\
32.4\end{array}$ & \\
\hline
\end{tabular}


Tabl e 10. Prey fi sh consuned by northern squaufi sh (SQF) wi thi n dam BRZ' s in the I ower Col unbi a and Snake Ri vers during 1990. See Table 8 for explanati on of col ums.

\begin{tabular}{|c|c|c|c|c|c|c|c|c|}
\hline \multirow[b]{2}{*}{$\begin{array}{c}\text { RESERVO R } \\
\text { Locat i on } \\
\text { (i n BRZ) }\end{array}$} & \multicolumn{2}{|c|}{ PREDATORS } & \multicolumn{6}{|c|}{ PREY FISH CONSUMED } \\
\hline & $\mathbf{N}$ & $\begin{array}{l}\text { Mean } \\
\text { FL ( } \mathbf{m})\end{array}$ & $\begin{array}{l}\text { Mean } \\
\text { Fi sh } \\
\text { wt. } \\
\text { (g) }\end{array}$ & $\begin{array}{c}\text { Total } \\
\# \\
\text { Smolts }\end{array}$ & $\begin{array}{l}\text { \# } \\
\text { Snol ts } \\
\text { Per } \\
\text { s SQF }\end{array}$ & $\begin{array}{c}\% \\
\text { Snol ts }\end{array}$ & $\begin{array}{l}\text { Total } \\
\# \\
\text { other } \\
\text { Fi sh }\end{array}$ & $\begin{array}{c}\% \\
\text { Other } \\
\text { Fish }\end{array}$ \\
\hline
\end{tabular}

\section{SPRI NG}

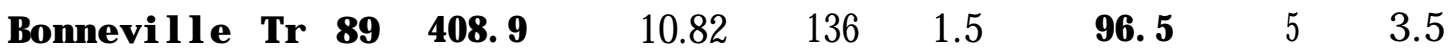
BONEY LLE

$\begin{array}{lllllrrr}\text { Bonnevi I l e Fb } \mathbf{1 0 2} & 402.2 & 3.43 & 32 & 0.3 & \mathbf{8 8 . 9} & 4 & 11.1\end{array}$

$\begin{array}{lllllllll}\text { The Dalles } \operatorname{Tr} 41 & 430.8 & 4.08 & 30 & 0.7 & 100.0 & 0 & 0.0\end{array}$

THE DALLES

$\begin{array}{lllllllll}\text { The Dal I es Fb } 21 & 435.2 & 8.14 & 14 & 0.7 & 100.0 & 0 & 0.0\end{array}$

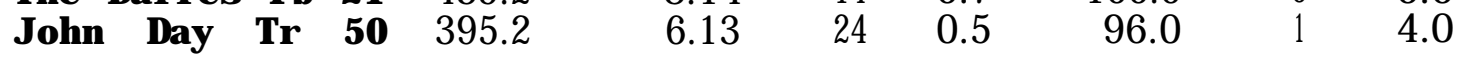
J OHN DAY

$\begin{array}{llllllllll}\text { J ohn Day } & \mathbf{F b} & \mathbf{3 4} & \mathbf{4 1 7 . 4} & 11.97 & 32 & 0.9 & 100.0 & 0 & 0.0\end{array}$
MCNARY

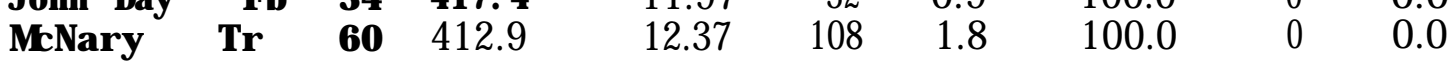

$\begin{array}{llllllllll}\text { MtNary } & \text { Fb } & \mathbf{1 7} & 446.1 & 21.88 & 28 & 1.6 & 96.6 & 1 & 3.4 \\ \text { Ice Har bor } & \text { Tr } & \mathbf{1 4} & 446.1 & 13.58 & 26 & 1.9 & 96.3 & 1 & 3.7\end{array}$

\section{SUMMER}

\begin{tabular}{|c|c|c|c|c|c|c|c|c|}
\hline $\begin{array}{c}\text { Bonnevi I l e Tr } \\
\text { ONEY }\end{array}$ & 109 & 375.9 & 5.63 & 122 & 1.1 & 96.1 & 5 & 3.9 \\
\hline $\begin{array}{l}\text { Bonnevill e Fb } \\
\text { The Dal l es Tr } \\
\text { THF DAl ES }\end{array}$ & $\begin{array}{l}89 \\
63\end{array}$ & $\begin{array}{l}388.8 \\
406.1\end{array}$ & $\begin{array}{r}5.1 \\
1.54\end{array}$ & $\begin{array}{r}49 \\
6\end{array}$ & $\begin{array}{l}0.6 \\
0.1\end{array}$ & $\begin{array}{l}92.5 \\
75.0\end{array}$ & $\begin{array}{l}4 \\
2\end{array}$ & $\begin{array}{r}7.5 \\
25.0\end{array}$ \\
\hline $\begin{array}{l}\text { The Dal I es Fb } \\
\text { J ohn Day Tr } \\
\text { J OHN DAY }\end{array}$ & $\begin{array}{l}25 \\
50\end{array}$ & $\begin{array}{l}390.3 \\
429.1\end{array}$ & $\begin{array}{l}1.37 \\
4.62\end{array}$ & $\begin{array}{r}8 \\
65\end{array}$ & $\begin{array}{l}0.3 \\
1.3\end{array}$ & $\begin{array}{r}88.9 \\
100.0\end{array}$ & $\begin{array}{l}1 \\
0\end{array}$ & $\begin{array}{r}11.1 \\
0.0\end{array}$ \\
\hline $\begin{array}{cc}\text { John Day } & \text { Fb } \\
\text { MeNary } & \text { Tr }\end{array}$ & $\begin{array}{l}11 \\
50\end{array}$ & $\begin{array}{l}\text { 405. } 1 \\
\text { 418. } 1\end{array}$ & $\begin{array}{l}\mathbf{0 . 1 2} \\
3.82\end{array}$ & $\begin{array}{r}2 \\
118\end{array}$ & $\begin{array}{l}0.2 \\
2.4\end{array}$ & $\begin{array}{l}66.7 \\
96.7\end{array}$ & $\begin{array}{l}1 \\
4\end{array}$ & $\begin{array}{r}33.3 \\
\mathbf{3 . 3}\end{array}$ \\
\hline $\begin{array}{l}\text { MtNary } \\
\text { Ice Har bor }\end{array}$ & $\begin{array}{r}8 \\
79\end{array}$ & $\begin{array}{l}392.9 \\
411.2\end{array}$ & $\begin{array}{l}1.43 \\
0.22\end{array}$ & $\begin{array}{l}4 \\
6\end{array}$ & $\begin{array}{l}0.5 \\
0.1\end{array}$ & $\begin{array}{l}100.0 \\
100.0\end{array}$ & $\begin{array}{l}0 \\
0\end{array}$ & $\begin{array}{l}0.0 \\
0.0\end{array}$ \\
\hline
\end{tabular}


Tabl e 11. Di et summary of northern squauf i sh i $n$ reservoi $r$ - wi de ( excl udi ng BRZ' s at dans) areas i $n$ the I ower Col unbi a and Snake Ri vers during 1990 sampling. See Table 7 for expl anati on of col ums.

\begin{tabular}{|c|c|c|c|c|c|c|c|c|c|}
\hline \multirow{2}{*}{$\begin{array}{c}\text { RESERVO R } \\
\text { ( excl udi ng } \\
\text { BRZ' s) }\end{array}$} & \multirow[b]{2}{*}{$\mathbf{N}$} & \multirow{2}{*}{$\begin{array}{l}\text { Mean } \\
\text { gut ut } \\
\text { (g) }\end{array}$} & \multirow{2}{*}{$\begin{array}{l}\% \\
\text { empt y } \\
\text { gut s }\end{array}$} & \multicolumn{6}{|c|}{ GT CONTENIS $(\%$} \\
\hline & & & & $\overline{\text { Fi sh }}$ & Crust. & MbI I. & I nsect & PI ant & Other \\
\hline SPRING & & & & & & & & & \\
\hline $\begin{array}{l}\text { Bonn. Tai I race } \\
\text { BONNEY LLE } \\
\text { THE DALLES } \\
\text { J OHN DAY } \\
\text { MCNARY }\end{array}$ & $\begin{array}{l}60 \\
27 \\
49\end{array}$ & $\begin{array}{l}5.99 \\
9.19 \\
6.51\end{array}$ & $\begin{array}{l}17.5 \\
22.2 \\
32.7\end{array}$ & $\begin{array}{l}38.6 \\
17.4 \\
21.4 \\
52.7 \\
35.8\end{array}$ & $\begin{array}{l}51.3 \\
70.1 \\
55.7 \\
37.6 \\
40.6\end{array}$ & $\begin{array}{l}5.5 \\
1.3 \\
4.4 \\
0.2 \\
1.9\end{array}$ & $\begin{array}{r}2.0 \\
3.8 \\
2.8 \\
9.5 \\
12.1\end{array}$ & $\begin{array}{r}2.6 \\
4.8 \\
11.1 \\
0.0 \\
0.3\end{array}$ & $\begin{array}{l}0.0 \\
2.6 \\
4.6 \\
0.0 \\
9.3\end{array}$ \\
\hline
\end{tabular}

SUMMER

\begin{tabular}{lrllrlrrrr} 
BONNEY LLE & 96 & $\mathbf{3 . 9 8}$ & $\mathbf{2 1 . 1}$ & 15.4 & 60.4 & 5.6 & 15.1 & 8.7 & 4.8 \\
THE DALLES & 133 & 2.82 & 33.1 & 1.8 & 60.0 & 3.3 & 17.2 & 10.3 & 7.4 \\
J OFN DAY & 37 & 7.22 & 45.9 & 38.1 & 41.8 & 7.0 & 5.5 & 1.7 & 5.8 \\
MCNARY & 83 & 5.47 & 36.1 & 20.2 & 52.7 & 1.5 & 6.6 & 14.0 & 5.1 \\
\hline
\end{tabular}


Table 12. Prey fi sh consuned by northern squaufi sh (SQF) in reservoi $r$-wi de areas in the I ower Col unbi a and Snake Ri vers duri ng 1990 sampl ing. See Table 8 for expl anation of col ums.

\begin{tabular}{|c|c|c|c|c|c|c|c|}
\hline \multirow[b]{2}{*}{$\begin{array}{l}\text { RESERVa R } \\
\text { (excl udi ng } \\
\text { BRZ' s) }\end{array}$} & \multicolumn{2}{|c|}{ PREDATORS } & \multicolumn{5}{|c|}{ PREY FISH CONSUMED } \\
\hline & $\mathbf{N}$ & $\begin{array}{l}\text { Mean } \\
\text { FL ( } \mathbf{m})\end{array}$ & $\begin{array}{l}\text { Mean } \\
\text { Fi sh Total } \\
\text { ut. \# } \\
\text { (g) Smolts }\end{array}$ & $\begin{array}{c}\# \\
\text { Snol ts } \\
\text { Per } \\
\text { SQF }\end{array}$ & $\begin{array}{c}\% \\
\% \\
\text { Snol ts }\end{array}$ & $\begin{array}{c}\text { Total } \\
\# \\
\text { other } \\
\text { Fi sh }\end{array}$ & $\begin{array}{c}\% \\
\text { Other } \\
\text { Fi sh }\end{array}$ \\
\hline
\end{tabular}

SPR NG

$\begin{array}{lrrrrrrrr}\text { Bonn. Tai I race } & \mathbf{6 0} & \mathbf{3 6 9 . 2} & \mathbf{1 . 3 3} & \mathbf{2 5} & \mathbf{0 . 4} & \mathbf{9 2 . 6} & 2 & \mathbf{7 . 4} \\ \text { BONEM LLE } & \mathbf{9 7} & \mathbf{3 6 3 . 1} & \mathbf{2 . 0 7} & \mathbf{3} & <0.1 & 14.3 & 18 & 85.7 \\ \text { THE DALLES } & 59 & 381.9 & \mathbf{1 . 7 8} & \mathbf{9} & 0.2 & \mathbf{7 5 . 0} & 2 & \mathbf{2 5} .0 \\ \text { J OHN DAY } & \mathbf{2 7} & \mathbf{4 1 3 . 7} & \mathbf{6 . 3 5} & \mathbf{1 8} & 0.7 & \mathbf{9 0 . 0} & 2 & 100 \\ \text { MCNARY } & \mathbf{4 9} & \mathbf{4 0 6 . 5} & \mathbf{2 . 9 4} & \mathbf{2 3} & \mathbf{0 . 5} & \mathbf{9 2 . 0} & & \mathbf{8} .0\end{array}$

SUMMER

$\begin{array}{lrllrrrrr}\text { Bonn. Tai I race } & \mathbf{4 6} & \mathbf{3 6 1 . 1} & \mathbf{0 . 0 4} & 0 & \mathbf{0 . 0} & 0.0 & \mathbf{0} & - \\ \text { BONNEM LLE } & \mathbf{9 6} & \mathbf{3 4 4 . 3} & \mathbf{0 . 1 4} & 2 & \mathbf{0 . 0} & 66.7 & 1 & 100.0 \\ \text { THE DALLES } & \mathbf{1 3 3} & \mathbf{3 5 6 . 7} & \mathbf{0 . 0 7} & 19 & <0.1 & \ldots . . & 4 & 33.3 \\ \text { J OHN DAY } & 37 & \mathbf{3 7 5 . 7} & 1.49 & & 0.5 & 82.6 & & \mathbf{1 7 . 4} \\ \text { MCNARY } & \mathbf{8 3} & \mathbf{3 8 5 . 2} & \mathbf{0 . 7 2} & 29 & 0.3 & \mathbf{8 5 . 3} & \mathbf{5} & \mathbf{1 4 . 7}\end{array}$


guts contained salmonid vertebrae or other non-diagnostic bones. The highest number of salmonids per gut were generally found in tailrace areas. Squawfish at mid-reservoir sites had the lowest number of salmonids.gut ${ }^{-1}$, except at the upper McNary location (Table 8). Northern squawfish within BRZ areas contained much higher numbers of juvenile salmonids $\left(0.9\right.$ salmonids $\cdot$ gut $^{-1}$; Table 10) than predators collected in the reservoir-wide areas $(0.2$ salmonids.gut ${ }^{-1} ;$ Table 12). Guts from northern squawfish collected in the spring period contained more juvenile salmonids than squawfish sampled in the summer. The spring samples contained fewer empty guts (25\%) than the summer samples (41\%; Table 7). The number of salmonids per gut (spring 0.7; summer 0.5 ) and prey fish weight per gut (spring $6.1 \mathrm{~g}$; summer $2.0 \mathrm{~g}$ ) were higher during the spring sampling period (Table 8), probably because of slower evacuation rates during spring when temperature was lower.

Other species of prey fish comprised only 7\% of the total number of fish ingested by northern squawish. In reservoirwide areas (Table 12), 26\% of the prey fish consumed were nonsalmonids, while only $4 \%$ of the prey fish consumed were nonsalmonids in the BRZ zones (Table 10). Sculpins made up 63\% of the other prey fish category and were mostly found in predators collected around Bonneville Dam and at Bonneville mid-reservoir area.

Age Determination of Northern Squawfish

Use of otoliths for determining ages of northern squawfish proved unsuccessful due to problems encountered while trying to prepare the otoliths for viewing. Most otoliths were brittle and shattered easily when ground with fine grit emery paper or sectioned with a dremmel tool. For these reasons we abandoned the use of otoliths for age determination. Ageing of subsamples of northern squawfish with scales and opercles is progressing. 
DISCUSSION

The goal of predation indexing is to provide a ranking of locations and reservoirs throughout the Columbia River Basin according to the intensity of predation upon juvenile salmonids. Predation indexing will require integration of consumption rate data with predator abundance data, which has not been completed. We have, however, provided some preliminary observations based upon the results of northern squawfish consumption indexing.

Northern squawfish consumption indices during 1990 were particularly high near hydroelectric projects, especially during the summer. Consumption indices tended to be several times higher, often an order of magnitude or more, in tailrace and forebay BRZ'S (Table 4) compared to CI estimates made by pooling predators from the non-BRZ portions of the reservoir (Table 6). The CI's in The Dalles tailrace BRZ and John Day forebay BRZ were exceptions to this pattern, having somewhat lower northern squawfish CI's than was observed in the BRZ's at the other dams. Such exceptions might be explained by sample timing, dam operation, project design (see Figure 2, e.g.) or other factors.

Catch per unit effort by ODFW and FWS electrofishing was relatively high near dams (preliminary data in Vigg and Burley 1990b) suggesting predator abundance may be high at these sites. Abundant predators and high consumption rates may result in significant juvenile salmonid losses near dams. Juvenile salmonids may also be more susceptible to predators immediately downstream of dams because of stress, disorientation, or injury caused by passage through the dam.

Sampling in the mainstem Columbia River reservoirs during 1990 was scheduled to coincide as close as possible with historical salmonid passage patterns. Examination of 1990 juvenile salmonid passage indices showed that sample scheduling was generally successful for consumption indexing (Figure 5). We used juvenile salmonid passage indices from individual dams as general indicators of salmonid abundance near that dam (forebay and tailrace), and also in the immediate, downstream reservoir. In the McNary and John Day reservoirs, sampling coincided well 

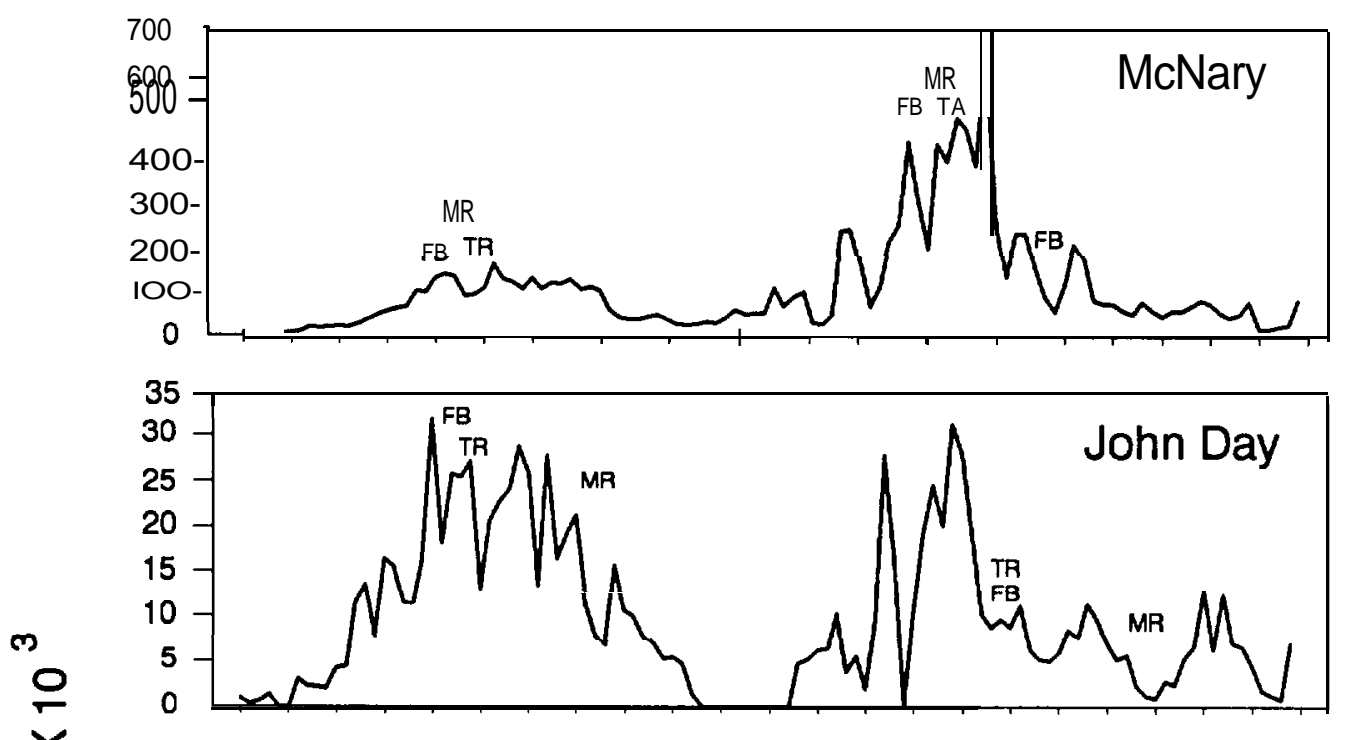

爻
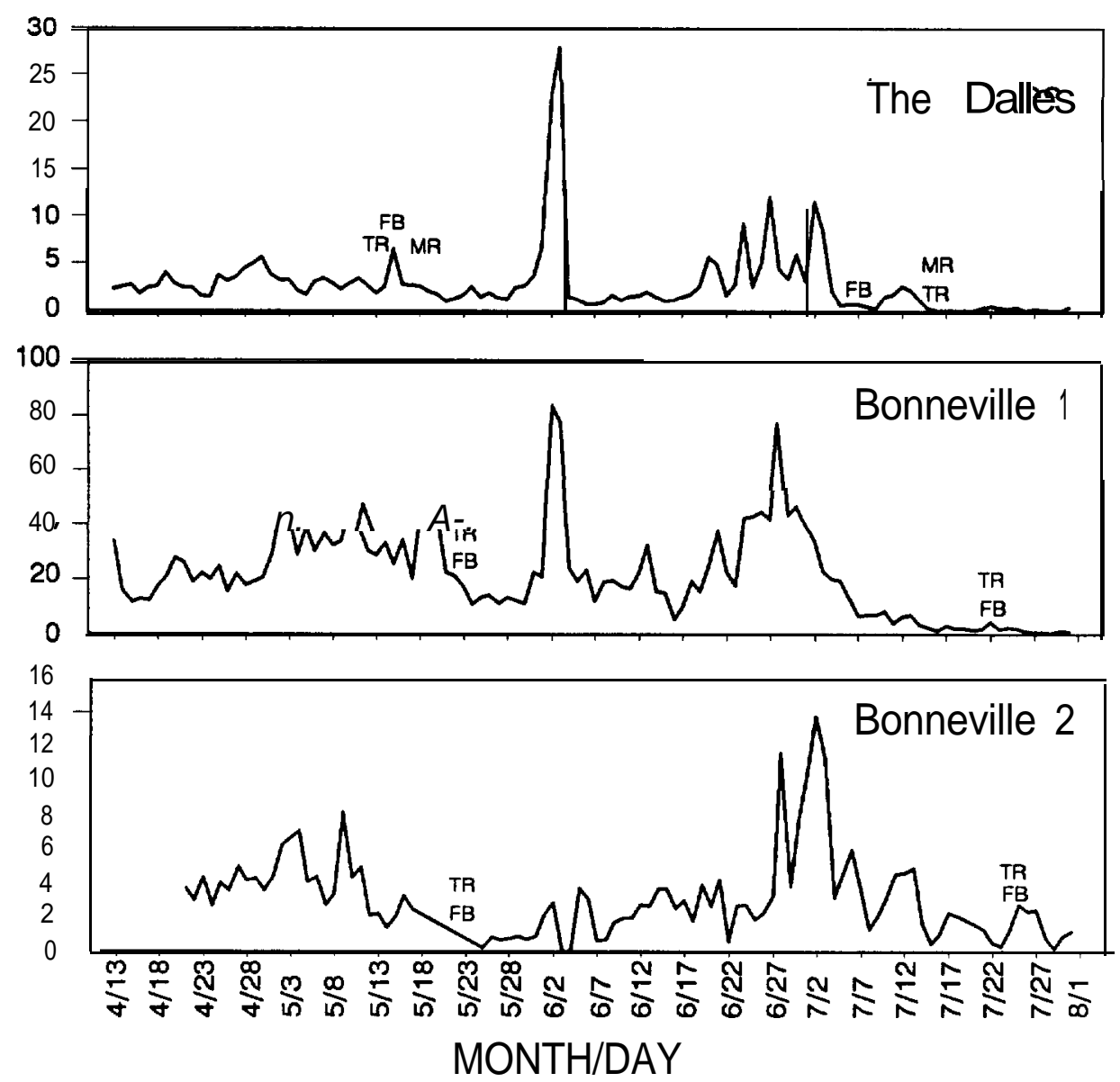

Figure 5. Timing of Consumption Index sampling during 1990 with respect to juvenile salmonid passage indices at mainstem dams. Approximate sample times for tailrace (TR), forebay (FB), and the immediate downstream mid-reservoir (MR) locations are shown in a panel. The MR locator in the John Day panel, for example, actually represents sampling within The Dalles mid-reservoir. Passage data from the Fish Passage Center 1990 Biweekly Reports. 
with the spring and summer salmonid out-migrations (Figure 5). In The Dalles and Bonneville reservoirs, spring sampling was toward the end of the period of highest salmonid abundance, when passage indices were gradually declining, but still fairly high. Summer sampling in the two lower reservoirs, especially in the Dalles Reservoir, missed the largest smolt passage period (about June, 20 through July, 10). Low prey densities during our summer sampling in The Dalles Reservoir might explain the low CI's observed in The Dalles forebay and mid-reservoir locations (Table 3). On the other hand, northern squawfish consumption indices were moderate to high in The Dalles forebay, Bonneville forebay and Bonneville tailrace even though passage indicies were low during sampling at these locations. This suggests that consumption indices were not simply a reflection prey density and consumption rate could be high even when passage was relatively low.

Collecting northern squawfish was most difficult at midreservoir locations, as expected, and considerably more fishing effort (at least double) would have been required to reach the original mid-reservoir sampling targets ( $\geq 60$ fish per two-day period). The variability of small-sample CI estimates were, however, narrow enough that rough CI comparisons could be made (CI/2 vs. CI Vs. $2{ }^{*} \mathrm{CI}$, e.g.) with high statistical power (>90\%). Comparisons of CI estimates from tailrace and forebay locations could be made with even greater confidence (higher power) because of the larger samples and tighter relative variability about the mean CI's.

In future studies, northern squawfish consumption and predation indices from the lower Columbia River (1990, this report), the lower Snake River (scheduled 1991) and the midColumbia River (planned 1992) will be compared to provide a relative ranking of juvenile salmonid losses to predators in different reservoirs. Since sampling in the lower Columbia River, the lower Snake River and the mid-Columbia River will be conducted in separate years (1990-92), direct comparisons of regional data will not be possible. The study design calls for 
John Day Reservoir to be sampled each year (1990-92), providing a scaler for inter-annual effects. Predation in John Day Reservoir was also studied in 1983-86 and 1988 (Poe et al. 1988; Petersen et al. 1990), supplying additional data for comparisons.

Use of a northern squawfish bioenergetics model will provide an alternative means of estimating juvenile salmonid consumption rate. Consumption rate estimation with fish energetic models has been advocated elsewhere (Rice and Cochran 1984; Bartell et al. 1986). Weight change of cohorts of fish will be used in modeling consumption rate and salmonid ration. Ongoing work on the age of northern squawfish in lower Columbia and Snake River reservoirs is required so average weights of cohorts can be estimated at different times from spring to fall. 


\section{LITERATURE CITED}

Bagenal, T. B. and F. W. Tesche. 1978. Age and growth. Pages 101-136 In: T. B. Bagenal (ed.) Methods for assessment of fish production in freshwater, 3rd Edition. Blackwell Scientific Publications, Oxford, England.

Bartell, S. M., J. E. Breck, R. H. Gardner and A. L. Brenkert. 1986. Individual parameter perturbation and error analysis of fish bioenergetics models. Can. J. Fish. Aquat. Sci. $43: 160-168$.

Beyer, J. M., G. Lucchetti, and G. Gray. 1988. Digestive tract evacuation in northern squawfish (Ptvchocheilus

oreaonensis). Can. J. Fish. Aquat. Sci. 45:548-553.

Efron, B. and R. Tibshirani, 1986. Bootstrap methods for standard errors, confidence intervals, and other measures of statistical accuracy. Statistical Science, 1:54-77.

Fickeisen, D. H., D. D. Dauble, and D. A. Neitzel. 1990. Proceedings of the predator-prey modeling workshop, Friday Harbor, Washington, May 16-19, 1989. Final contract (DEAC06-76RLO-1830) completion report to Bonneville Power Administration, Portland, Oregon.

Hewett, S. W. and B. L. Johnson. 1987. A generalized bioenergetics model of fish growth for microcomputers. University of Wisconsin Sea Grant Institute, Report No. WISSG-87-245.

Hewett, S. W. and B. L. Johnson. 1989. A general bioenergetics model for fishes. American Fisheries Society Symposium, $6: 206-208$.

Jearld, W. E. 1983. Age determination. Pages 301-323 In: L. A. Nielson and D. L. Johnson (eds.), Fisheries techniques. Am. Fish. Soc., Bethesda, MD.

McConnell, W. J. 1952. The opercular bone as an indicator of age and growth of the carp, Cynrinus carpio Linnaeus. Trans. Am. Fish. Soc. 81:138-149.

Nigro, A. A., S. Vigg and C. Burley. 1990. Development of a system-wide predator control program: Stepwise implementation of a predation index, predator control fisheries, and evaluation plan in the Columbia River Basin. Annual Progress Report, August 1988 - September 1989, Project Summary. Project Number 82-028, Bonneville Power Administration, Portland, Oregon. 
Petersen, J. H., M. G. Mesa, J. Hall-Griswold, W. C. Schrader, G. W. Short and T. P. Poe. 1990. Magnitude and dynamics of predation on juvenile salmonids in Columbia and Snake River reservoirs. Annual Report of Research, 1989-1990. Bonneville Power Administration, Portland, Oregon.

Poe, T. P. and B. E. Rieman (eds.). 1988. Predation by resident fish on juvenile salmonids in John Day Reservoir, 1983-86. Final Report, (Contracts DE-A179-82BP34796 and DE-A17982BP35097) Bonneville Power Administration, Portland, Oregon.

Rice, J. A. and P. A. Cochran. 1984. Independent evaluation of a bioenergetics model for largemouth bass. Ecology 65:732739.

Rieman, B. E., R. C. Beamesderfer, S. Vigg and T. P. Poe. 1988. Predation by resident fish on juvenile salmonids in a mainstem Columbia Reservoir: Part IV. Estimated total loss and mortality of juvenile salmonids to northern squawfish, walleye, and smallmouth bass. In: Poe, T. P. and B. E. Rieman (eds.), 1988. Predation by resident fish on juvenile salmonids in John Day Reservoir, 1983-86. Final Report, (Contracts DE-A179-82BP34796 and DE-A179-82BP35097)

Bonneville Power Administration, Portland, Oregon.

Scoppettone, G. G. 1988. Growth and longevity of the Cui-ui and longevity of other catostomids and cyprinids in western North America. Trans. Am. Fish. Soc. 117:301-307.

Seaburg, K. G. 1957. A stomach sampler for live fish. Prog. Fish Cult. 19:137-139.

Vigg, s., T. P. Poe, L. A. Prendergast, and H. C. Hansel, 1988. Predation by resident fish on juvenile salmonids in a mainstem Columbia River Reservoir: Part II. Consumption rates of northern squawfish, walleye, smallmouth bass, and channel catfish. In: Poe, T. P. and B. E. Rieman (eds.), 1988. Predation by resident fish on juvenile salmonids in John Day Reservoir, 1983-86. Final Report, (Contracts DEA179-82BP34796 and DE-A179-82BP35097) Bonneville Power Administration, Portland, Oregon.

Vigg, S. and C. C. Burley. 1990a. Report A - Developing a predation index and evaluating ways to reduce juvenile salmonid losses to predation in the Columbia River. In: Nigro, A. A. (ea.), 1990. Developing a predation index and evaluating ways to reduce salmonid losses to predation in the Columbia River Basin. 1989 Annual Progress Report. Bonneville Power Administration, Portland, Oregon.

ViggI S. and C. C. Burley. 1990b. DRAFT REPORT. Summary of catch per unit effort (CPUE) of commercial fisheries, sport reward fisheries, dam angling, and indexing. 
Appendix A. Description of consumption indexing database.

\section{DATABASE DEVELOPMENT AND DATA PROCESSING}

A relational database program was used to organize and store field and laboratory data. A relational database is a set of linked tables, each table containing a particular category of data(i.e., transect data and predator data). Data integrity is enhanced as information is shared among tables. For example, if a column is defined in one table to have a particular data type, a new table with the same column will automatically have the same data type. Common columns among tables allow a user to manipulate several tables at a time. Two or more tables that share at least one column can be combined for query or data output purposes. Several relational commands are available that combine identical rows and/or columns. Redundant data entry and associated error are also decreased by having an efficient database.

\section{TABLE AND COLUMN DEFINITIONS}

Consumption indexing field data were separated into two master tables and linked by a collection number (COLLECT\#. Figure Al). Each transect was assigned a unique "collection number" and each predator within a transect was given a unique "predator number" (NUMBER). Transect information was placed into the MTRNSECT table and predator data within transects were entered to the MPREDATR table.

As each transect possibly contained several predators and each predator was related to only one transect, a one-to-many relationship was represented between the two tables. This arrangement permitted one-time entry of transect data for all of the predators collected within that transect, reducing table size and allowing individual predator data to be stored in a separate table. Diet data were contained in a table named MPREYDAT which was linked to the MPREDATR table by the common columns COLLECT\# and NUMBER, and to the MTRNSECT table by COLLECT\#. (Figure Al). 


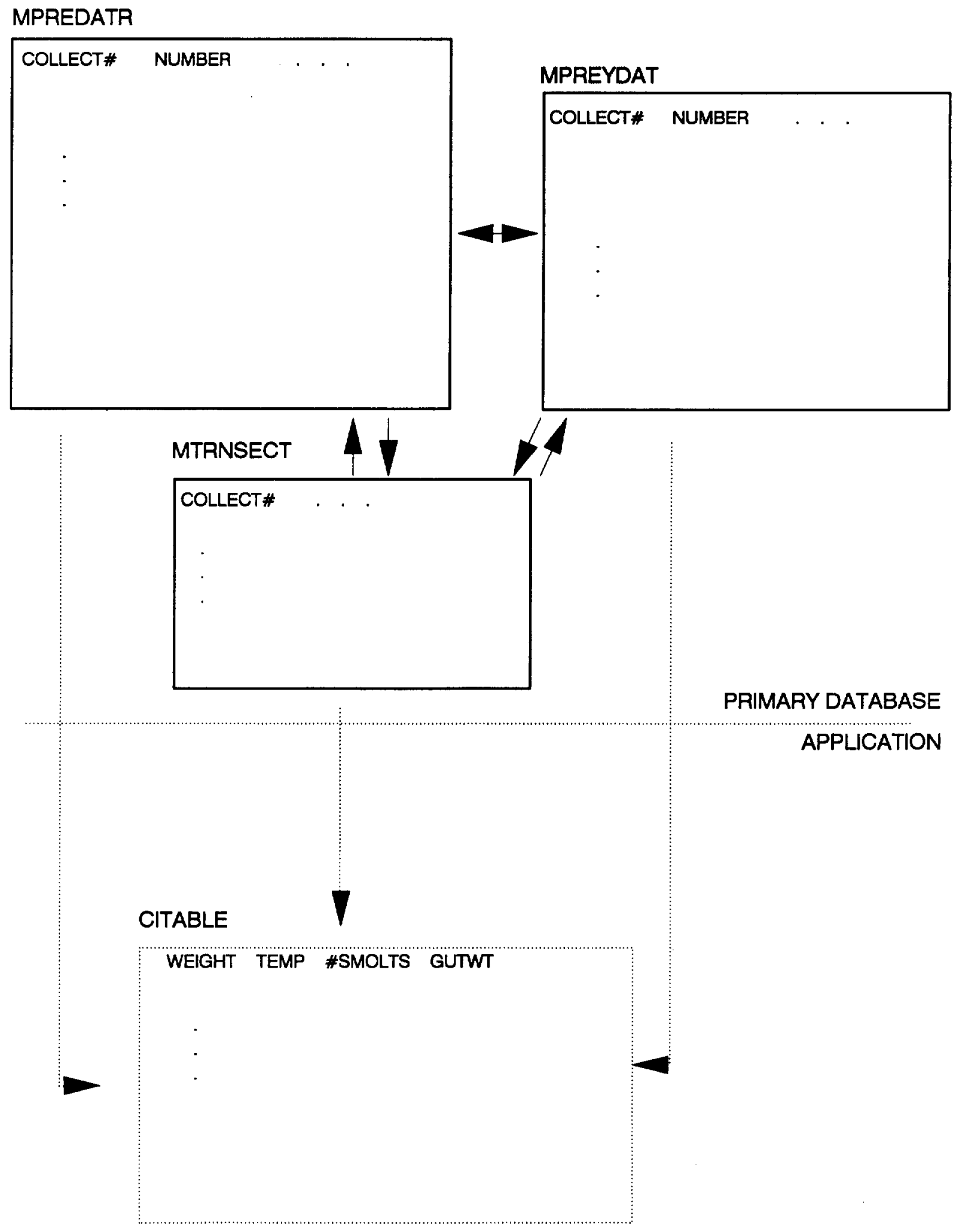

Figure A1. Schematic representation of master tables and application of relational design. Only common columns are shown. Rows represent each unique set of data. Table name is above each box. Variable names are listed in Table A1. 
MPREYDAT contained diet information for every predator from which a stomach sample was taken. Column names and data types were defined for each appropriate table and expressions were written for computed columns. Table Al lists the column names and data types for each master table and displays which columns were common between tables.

\section{DATA ENTRY AND EDITING}

Keyboard data-entry was facilitated by defining forms that closely resembled the data sheets. Entry errors were minimized by limiting the values or text that could be entered into a particular field on a form. Commands for sorting were used to arrange rows of data sequentially for tabular editing. A hard copy of each master table was printed and proofed for errors. After a final edit the tables were ready for creating subsets to be used for data analysis.

COMBINING VARIABLES AND PROJECTING DATA SUBSETS

Several options were available which joined selected columns/variables from two or more tables. Subsets of the new tables were used for data analysis. For example, catch summary information for species by location and date was extracted from a table that contained selected predator and transect data. Datasets that were to be analyzed by other software applications were exported to appropriate files, such as ASCII or Lotus spreadsheet files.

\section{FILE ARCHIVES}

The entire database, including structure definition and indices for keyed columns was stored as three files. The working database was written to a hard disk on an IBM AT. Two archival copies were kept on floppy diskettes and stored separately. A second copy of the working set was stored on a separate microcomputer. Revisions from the first working copy were updated to the archival files on a weekly basis. 
TABLE Al. DATABASE VARIABLES AND DESCRIPTIVE DEFINITIONS FOR PRINCIPLE TABLES

\section{TABLE MTRNSECT}

VARIABLE NAME

LOCATION

DATE

COLLECT\#

CREW

BOAT

GEAR

TEMP

WEATHER

STARTTIM

STOPTIME

COMMENTS

RANDOM

COLLECT\#

NUMBER

SPECIES

FORKLENG

WEIGHT

SEX

SCALE

MATURITY

DISPOSTN

COMMENT2

\section{DESCRIPTION}

6 digit code defines spatial data Sampling date

Collection number unique for each transect

Code for capture method

Recorded temperature

Code for weather condition

Military time for start of transect Military time for end of transect

Text for unusual circumstances

Designates whether transect was selected randomly (for CPUE)

\section{TABLE MPREDATR}

Common variable linked to MTRNSECT

Predator number unique for each

predator within a transect

Text value (3 characters)

Forklength

Predator weight

One digit code

One digit code to indicate whether

a scale sample was taken

Indicated sexual maturity

Code to indicate disposition of the predator

Text to remark on unusual

characteristics 
TABLE Al. (Continued) DATABASE VARIABLES AND DESCRIPTIVE DEFINITIONS FOR PRINCIPLE TABLES

\section{TABLE MPREYDAT}

COLLECT\#

NUMBER

PROCESS\#

ANALYZER

FISHWT

PREY1

CODE1

PREY2

CODE2

OTHERPRY

CODE3

TOTALWT

\#SMOLTS

\#SCULP IN

\#OTHER

\#UNIDSAL

\#UNIDOTH

COMMENT3
Common variable linked to MPREDATR and MTRNSECT

Common variable linked to MPREDATR

Lab number for each predator

Grams of fish found in stomach

sample

Grams of prey item \#l excluding fish

ID code for PREY1

Grams of prey item \#2 excluding fish

ID code for PREY2

Grams of prey item \#3 excluding fish

ID code for OTHERPRY

Sum(in grams) of all prey items

Number of smolts identified/sample Number of sculpins identified/sample

Number of other fish identified/sample

Incidence of unidentified salmonids/sample

Incidence of unidentified other fish/sample

Remarks about prey items 
Appendix B. DRAFT Summary Report - Effects of temperature upon respiration rates of northern sguawfish (Ptvchocheilus oreaonensis).

NORTHERN SQUAWFISH 0, CONSUMPTION RATE: EFFECTS OF TEMPERATURE

$$
\begin{gathered}
\text { by } \\
\text { Joseph J. Cech, Jr.', Daniel T. Castleberry,2,3, } \\
\text { Todd E. Hopkins }{ }^{1,2} \text {, and James H. Petersen } \\
\text { 'Department of Wildlife and Fisheries Biology } \\
\text { University of California, Davis } \\
\text { Davis, California. 95616 } \\
\text { 'National Fisheries Research Center, } \\
\text { Columbia River Field Station, } \\
\text { U.S. Fish and Wildlife Service } \\
\text { Star Route, Cook, Washington. } 98605
\end{gathered}
$$

${ }^{3}$ Dixon Field Station, National Fisheries Contaminant Research Center, U.S. Fish and Wildlife Service, 6924 Tremont Rd., Dixon, California. 95620 


\section{Abstract}

Northern squawfish, Ptvchocheilus oresonensis, (live weight range: 0.225 - $1.973 \mathrm{~kg}$ ) were caught by electrofishing in the Columbia River and held in continuous-flow tanks at 9, 15, 18, or $21^{\circ} \mathrm{C}$. Fish were placed into temperature-controlled, flow-through respirometers which incorporated an automated dissolved 0 , measuring system. 0 , consumption data were collected at ca. 90 min intervals for $>24 \mathrm{~h}$. Mean $( \pm 2 \mathrm{SE}$ ) standard 0, consumption rate of northern squawfish increased with acclimation temperature: $24.3 \pm 2.2 \mathrm{mg}^{\cdot} \mathrm{kg}^{-0.67} \cdot \mathrm{h}^{-1}$ at $9^{\circ} \mathrm{C}, 49.1 \pm 6.6 \mathrm{mg}^{\cdot} \mathrm{kg}^{-0.67} \cdot \mathrm{h}^{-1}$ at $15^{\circ} \mathrm{C}, 75.0 \pm 8.7 \mathrm{mg}^{\cdot} \mathrm{kg}^{-0.67} \cdot \mathrm{h}^{-1}$ at $18^{\circ} \mathrm{C}$, and $85.9 \pm 26.6 \mathrm{mg}^{\circ} \mathrm{kg}^{-}$ $0.67 . \mathrm{h}^{-1}$ at $21^{\circ} \mathrm{C}$. $\mathbf{Q}_{10}$ analysis showed that 0 , consumption rate temperature sensitivity was greatest at the intermediate acclimation temperatures $\left(15-18^{\circ} \mathbf{C}, \mathbf{Q}_{10}=4.10\right)$, moderate at the lower acclimation temperatures $\left(9-15^{\circ} \mathrm{C}, \mathbf{Q}_{10}=3.23\right)$, and lowest at the higher acclimation temperatures $\left(18-21^{\circ} \mathrm{C}, \mathbf{Q}_{10}=1.57\right)$. Overall $Q_{10}$ was $2.86\left(9-21^{\circ} \mathrm{C}\right)$. Generally, northern squawfish 0 , consumption rates more closely approximated those of other predatory fishes rather than those of lacustrine, omnivorous cyprinids. 
The northern squawfish, Ptvchocheilus oreaonensis, is a predaceous cyprinid fish inhabiting fresh water habitats in Oregon, Washington,' British Columbia and Alberta (Scott and Crossman 1973). Squawfish predation on juvenile salmonid fishes in the heavily modified Columbia River system has stimulated research on squawfish bioenergetics, including the construction of mathematical models (Rieman and Beamesderfer 1990). An important component of bioenergetic models is standard metabolic rate, the basal energy requirement for body maintenance (reviewed by Fry 1971 and Brett and Groves 1979).

Our objective was to measure standard 0 , consumption rates, as a measure of respiratory metabolism) for adult northern squawfish at temperatures which spanned the summer conditions in the Columbia River. We also compared northern squawfish 0, consumption rates with those for other omnivorous species in the same family and with other predaceous freshwater teleosts.

Materials and Methods

Adult northern squawfish were collected by electrofishing in the Columbia River near Bonneville Dam on June 14, 1990. Fish were quickly transported in oxygenated tanks to the USFWS Columbia River Field Station laboratory and held in circular, flowing water tanks $(1.2 \mathrm{~m}$ diameter, $1400 \mathrm{~L})$ for $>3 \mathrm{wk}$ at acclimation temperatures of $9,15,18$, or $21^{\circ} \mathrm{C}$. Only three temperatures could be maintained at one time, so fish were randomly assorted, by weight class, into 9,15 and $21^{\circ} \mathrm{C}$ acclimation groups. The $18^{\circ} \mathrm{C}$ group of fish consisted of remaining northern squawfish and did not include as broad a range of weights as the other temperature groups. Natural light cycles were maintained and fish were fed juvenile salmonids (about 1 prey•day ${ }^{-1}$ ) until respiration experiments. Water source was the Little White 
Salmon River, a tributary of the Columbia River.

Fish were inserted in appropriately sized, flow-through respirometers $(5 \mathrm{~L}$ or $13 \mathrm{~L})$ for 0 , consumption rate $\left(\mathbf{M O}_{2}\right)$ measurements. Respirometers were situated in $250-\mathrm{L}$, insulated fiberglass water baths which were interconnected with submersible pumps and siphons. Due to time and space constraints, experiments on fish at each acclimation temperature were all conducted within a several-day period. Experiments were conducted in the order: $9(\mathrm{n}=18), 15(\mathrm{n}=16), 21(\mathrm{n}=15), \mathbf{1 8}^{\circ} \mathrm{C}$ $(\mathrm{n}=16)$. Water temperature in the baths was regulated by thermostatted (YSI model 72 proportional temperature controllers) glass immersion heaters balanced against a continuous inflow of cold $\left(8^{\circ} \mathrm{C}\right)$ water from the Little white Salmon River. Particle filters (Teel model 2P275/2P369) which trapped particles >25um, continuously cleaned water in the system. Water from the interconnected baths was pumped in excess to an insulated, plastic reservoir incorporating an overflow standpipe, which maintained a constant pressure head and flow of water to the respirometers. Outflowing water from the respirometers was split by a $Y$ fitting into two tubes. One tube incorporated an in-line solenoid valve and led to a manifold with a calibrated, 0 , electrode (Nester model 617034) whereas the other tube returned water to the bath. The 0 , electrode was wired to a Nester digital 0, meter (model 8500) and stripchart recorder (Soltec Model 310). Solenoids were wired to an electronic sprinkler timer (Toro model EL-12t) such that valves sequentially opened at ca. 9 min intervals, sampling water from respirometers with fish, respirometers without fish (blank controls), and a tube without a respirometer (inflow water). Water flow rates were measured by the timed collection of water from tank outflow tubes (when solenoids were closed). MO, (mg $\left.\mathbf{k g}^{-0.67} \cdot \mathbf{h}^{-1}\right)$ was calculated using:

$$
\mathrm{MO},=\left(\mathrm{O}_{2} \text { in }-\mathrm{O}_{2} \text { out }\right)(\mathrm{VW} \cdot 60)\left(1000 / \mathrm{M}_{\mathrm{b}}\right)^{0.67}
$$

where: $\quad \mathrm{O}_{2}$ in $=$ inflowing $\left[\mathrm{O}_{2}\right]$ in $\mathrm{mg} / \mathrm{L}$, 


$$
\begin{aligned}
& \mathrm{O}_{\mathbf{2}} \text { out }=\text { outflowing }\left[\mathrm{O}_{2}\right] \text { in } \mathbf{m g} / \mathrm{L}, \\
& \mathrm{VW} \quad=\text { water flow in } \mathrm{L} / \mathrm{min}, \text { and } \\
& \mathbf{M}_{\mathbf{b}}=\text { live body mass of fish in } \mathrm{g} .
\end{aligned}
$$

Standard MO, was determined by calculating the mean of the two lowest MO, values measured over the $24+\mathrm{h}$ experiment for each fish. Mean $\mathbf{M} \mathbf{O}_{\mathbf{2}} \mathbf{s}$ at each temperature were compared using ANOVA followed by appropriate hypothesis tests (Wilkinson 1988).

\section{Results}

Mean, standard, mass-independent MO, of northern squawfish increased with increasing acclimation temperature. Mean ( $\pm 2 \mathrm{SE}$ ) rates were: $24.3 \pm 2.2$ at $9^{\circ} \mathrm{C}, 49.1 \pm 6.6$ at $15^{\circ}, 75.0 \pm 8.7$ at $18^{\circ}$, and $85.9 \pm 26.6$ at $21^{\circ}$. Data for individual specimens are shown in Table Bl. The increases between 9 and $15^{\circ}$, and between 15 and $18^{\circ}$ were significant $(\mathbf{p}<0.05)$. $\mathbf{Q}_{10}$ analyses (SchmldtNielsen 1975) showed that mo, sensitivity was greatest at the intermediate acclimation temperatures $\left(15-18^{\circ} \mathbf{C}, \mathbf{Q}_{10}=4.10\right)$, moderate at the lower acclimation temperatures $\left(9-15^{\circ} \mathbf{C}, \mathbf{Q}_{10}=\right.$ 3.23), and lowest at the higher acclimation temperatures (18 $\left.21^{\circ} \mathrm{C}, \mathbf{Q}_{10}=1.57\right)$. The overall $\mathbf{Q}_{10}$ was $2.86\left(9-21^{\circ} \mathrm{C}\right)$.

\section{Discussion}

Our northern squawfish data seem realistic as measures of standard metabolism because the rates approximate those of other species with similar feeding habits (Table B2). Also, our data are consistently below resting routine 0 , consumption rates measured for the congeneric Sacramento squawfish, $\underline{\mathbf{P}}$ arandis (Table B2). Resting routine $\mathbf{O}_{2}$ consumption rates (Cech 1990) are defined as those exhibited by quiescent fish, but not necessarily 
the lowest rates over the $24 \mathrm{~h}$ diurnal cycle. Cech et al. (1990) measured resting routine 0 , consumption rates for rainbow trout which also consistently exceed standard 0 , consumption rates (Table B2) .

Northern squawfish MO, temperature sensitivity varied with the acclimation temperature range. Other species have also shown $\mathbf{Q}_{10}$ variations through acclimation temperature ranges. For example, $\mathrm{MO}_{2} \mathrm{Q}_{10} \mathrm{~s}$ for rainbow trout were 3.5 between 4 and $10^{\circ} \mathrm{C}$ and only 1.7 between 12 and $22^{\circ} \mathrm{C}$ (Muller-Feuga et al. 1978). Baltz et al. (1982) calculated $\mathbf{Q}_{10}$ s ranging from $1.05\left(10-15^{\circ} \mathrm{C}\right)$ to 3.21 (25 $27.5^{\circ} \mathrm{C}$ ) for speckled dace, Rhinichthvs osculus (Cyprinidae). Utah chub, Gila atraria (Cyprinidae), show standard MO, $\mathbf{Q}_{10} \mathbf{s}$ ranging from $2.24\left(6-9^{\circ} \mathrm{C}\right)$ to $5.05\left(12-18^{\circ} \mathrm{C}\right)$, as calculated from Rajagopal and Kramer's (1978) data. The Sacramento squawfish shows a reduced resting routine $\mathrm{MO}_{2}$ temperature sensitivity at moderate temperatures $\left(15-20^{\circ} \mathrm{C}, \mathbf{Q}_{10}=1.20\right)$, compared with those at more extreme temperatures $\left(10-15^{\circ} \mathbf{C}, \mathbf{Q}_{10}{ }^{\prime}=\right.$ $\left.4.18 ; 25-30^{\circ} \mathrm{C}, \mathbf{Q}_{10}=2.36\right)$, as calculated from Cech's et al. (1990) data. Curiously, this appears to be the opposite pattern shown by the standard MO, data of its congener, northern squawish (Table Bl), albeit through a smaller temperature range.

Comparisons with other species in the family Cyprinidae show that northern squawfish have higher standard MO,. Beamish (1964) calculated standard MO, of carp, Cvorinus carnio, from extrapolation of $\log \mathrm{MO}$, at various activity levels to zero activity. Beamish and Mookherjii (1964) used the same technique to calculate standard MO, of goldfish, Carrassius carpio.

Although the experimental temperatures do not coincide with those used in our study, both carp and goldfish seem to have lower standard $\mathbf{M O}_{2} \mathbf{s}$ than northern squawfish (Table B2). Whereas both carp and goldfish generally inhabit quiet or slowly moving water and are omnivorous and generally do not chase moving prey such as small fish, squawfish are predators (reviewed by Moyle 1976, Scott and Crossman 1973). One might predict that northern 
squawfish would have higher standard $\mathbf{M O}_{2} \mathbf{s}$, perhaps accompanying larger red muscle masses. Larger red muscle masses typify more active species (Bainbridge 1960, 1962), and red muscle has higher tissue 0, demands than white muscle (Gordon 1968, Lin et al. 1974, Itazawa and Oikawa, 1983). Red muscle mass comparisons of northern squawfish with other species have not yet been made.

Comparisons with other predatory species show that northern squawfish have similar $\mathbf{M O}_{2} \mathbf{s}$ to rainbow trout, Oncorhvnchus mvkiss, and to walleye, Stizostedion vitreum. Using the extrapolation technique outlined above, Rao (1968) and Dickson and Kramer (1971) showed that both wild and hatchery rainbow trout have comparable $\mathbf{M O}_{2}$ s to northern squawfish (Table B2). Tarby (1981) used acrylic, flow-through respirometers similar to those which we used and showed that walleye have similar standard $\mathbf{M O}_{2} \mathbf{s}$ to northern squawfish (Table B2). Both rainbow trout and walleye exist in the Columbia River system.

In conclusion, northern squawfish displayed standard $\mathbf{M O}_{2} \mathbf{s}$ comparable to other predatory fishes in its environment. Northern squawfish standard MO, increased to varying extents with increasing acclimation temperature. Temperature sensitivity of northern squawfish standard MO, showed a peak at intermediate temperatures $\left(15-18^{\circ} \mathrm{C}\right)$, compared with lower $\left(9-15^{\circ} \mathrm{C}\right)$ and higher $\left(18-21{ }^{\circ} \mathrm{C}\right)$ temperatures. Future studies are needed to assess the effects of water current (swimming) on northern squawfish MO, .

\section{ACKNOWLEDGMENTS}

We thank Dena Gadomski, R. D. Nelle, Rip Shively and Roger Tabor for assistance with fish capture and care. Research was supported by the Bonneville Power Administration (Contract No. DE-AI79-90BP07096 to DTC, TEH, JHP) and by the University of California Agricultural Experiment Station (grant no. 3455-H to JJC) . 


\section{LITERATURE CITED}

Bainbridge, $R$. 1960. Speed and stamina in three fish. J. Exp. Biol. 37:129-153.

Bainbridge, R. 1962. Training, speed and stamina in trout. J. Exp. Biol. 39:537-555.

Baltz, D.M., P.B. Moyle, and N.J. Knight. Competitive interactions between benthic stream fishes, riffle sculpin, Cottus cfulosus, and speckled dace, Rhinichthvs osculus. Can. J. Fish. Aquat. Sci. 39:1502-1511.

Beamish, F.W.H. 1964. Respiration of fishes with special emphasis on standard oxygen consumption. II. influence of weight and temperature on respiration of several species. Can. J. Zool. $42: 177-188$.

Beamish, F.W.H. and P.S. Mookherjii. 1964. Respiration of fishes with special emphasis on standard oxygen consumption. I. influence of weight and temperature on respiration of goldfish, Carrassius auratus L. Can. J. Zool. 42:161-175.

Brett, J.R. 1964. The respiratory metabolism and swimming performance of young sockeye salmon. J. Fish. Res. Bd. Can. $21: 1183-1226$.

Brett, J.R. and T.D.D. Groves. 1979. Physiological energetics. PP. 279-352. In: W.S. Hoar, D.J. Randall, and J.R. Brett (eds.) Fish physiology. Vol. 8. Academic Press, New York.

Cech, J.J., Jr. 1990. Respirometry. In: C.B. Shreck and P.B. Moyle (eds.) Methods in Biology of Fishes. Amer. Fish. Soc. Publ. Bethesda. (In press)

Cech, J.J., Jr., S.J. Mitchell, and M.J. Massingill. 1979. Respiratory adaptations of Sacramento blackfish, orthodon microlenidotus (Ayres), for hypoxia. Comp. Biochem. Physiol. 63A: $411-415$.

Cech, J.J., Jr., S.J. Mitchell, D.T. Castleberry, and M. McEnroe. 1990. Distribution of California stream fishes: influence of environmental temperature and hypoxia. Env. Biol. Fish. 29:95105.

Fry, F.E.J. 1971. The effect of environmental factors on the physiology of fish. pp. 1-98. In: W.S. Hoar and D.J. Randall (eds.) Fish physiology. Vol. 6. Academic Press. New York.

Dickson, I.W. and R.H. Kramer. 1971. Factors influencing scope for activity and active and standard metabolism of rainbow trout (Salmo sairdneri). J. Fish. Res. Bd. Can. 28:587-596. 
Gordon, M.S. 1968. Oxygen consumption of red and white muscles from tuna fishes. Science 159:87-90.

Itazawa, Y. and S. Oikawa. 1983. Metabolic rates in excised tissues of carp. Experientia 39:160-161.

Lin, Y., G.H. Dobbs, III, and A.L. DeVries. 1974. Oxygen consumption and lipid content in red and white muscles of Antarctic fishes. J. Exp. Zool. 189:379-386.

Moyle, P.B. 1976. Inland fishes of California. Univ. Calif. Press. Berkeley.

Muller-Feuga, A., J. Petit, and J.J. Sabaut. 1978. The influence of temperature and wet weight on the oxygen demand of rainbow trout (Salmo aairdneri R.) in fresh water. Aquaculture 14:355363.

Rajagopal, P.K. and R.H. Kramer. 1974. Respiratory metabolism of Utah chub, Gila atraria (Girard) and speckled dace, Rhinichthvs osculus (Girard). J.Fish Biol. 6:215-222.

Rao, G.M.M. 1968. Oxygen consumption of rainbow trout (Salmo aairdneri) in relation to activity and salinity. Can. J. Zool. 46:781-786.

Rieman, B.E. and R.C. Beamesderfer. 1990. Dynamics of a northern squawfish population and the potential to reduce predation on juvenile salmonids in a Columbia River reservoir. N.Amer. J. Fish. Manage. 10:228-241.

Scott, W.B. and E.J. Crossman. 1973. Freshwater fishes of Canada. Fish. Res. Bd. Can. Bull. 184. Ottawa.

Tarby, M.J. 1981. Metabolic expenditure of walleye (Stizostedion vitreum vitreum) as determined by rate of oxygen consumption. Can J. Z001. 59:882-889.

Wilkinson, L. 1988. SYSTAT: the system for statistics. SYSTAT, Inc. Evanston. 
Table Bl. Mass ( $\mathbf{g})$, standard lengths (SL in $\mathrm{cm}$ ), and standard, mass-independent metabolic rates $\left(\mathbf{m g O}_{\mathbf{2}} \mathbf{~ k g}^{-2 / 3} \mathrm{hr}\right.$ ) for fish at each acclimation temperature.

\begin{tabular}{|c|c|c|c|c|c|c|c|c|c|c|c|c|}
\hline \multicolumn{2}{|c|}{ Temp } & \multicolumn{2}{|c|}{$9^{\circ} \mathrm{C}$} & \multicolumn{3}{|c|}{$15^{\circ} \mathrm{C}$} & \multicolumn{3}{|c|}{$18^{\circ} \mathrm{C}$} & \multicolumn{3}{|c|}{$21^{\circ} \mathrm{C}$} \\
\hline & Mass & SL & $\mathrm{MO}_{2}$ & Mass & SL & $\mathrm{MO}_{2}$ & Mass & SL & MO 2 & Mass & SL & $\mathrm{MO}_{2}$ \\
\hline & 903 & 36 & 21.4 & 665 & 37 & 46. 2 & 908 & 39 & 56. 8 & 1065 & 49 & 35.2 \\
\hline & 443 & 29 & 32.2 & 584 & 34 & 41.9 & 1161 & 42 & 73.0 & 1412 & 44 & 84. 2 \\
\hline & 459 & 28 & 23.4 & 1181 & 39 & 57.7 & 958 & 41 & 49. 7 & 1570 & 46 & 28. 1 \\
\hline & 1561 & 42 & 22.6 & 1314 & 43 & 39. 9 & 1268 & 44 & 66.7 & 1602 & 47 & 128. 3 \\
\hline & 1856 & 43 & 27.8 & 1856 & 47 & 73.8 & 1144 & 42 & 93. 9 & 512 & 33 & 145. 7 \\
\hline & 1088 & 38 & 22.6 & 439 & 30 & 49.4 & 1106 & 40 & 81.4 & 740 & 38 & 58. 7 \\
\hline & 448 & 31 & 19. 2 & 415 & 31 & 28. 7 & 1220 & 42 & 62.2 & 670 & 36 & 70. 3 \\
\hline & 924 & 40 & 24.8 & 974 & 40 & 40.1 & 1008 & 42 & 72.9 & 225 & 25 & 36.9 \\
\hline & 976 & 41 & 22.0 & 1209 & 41 & 71.7 & 1340 & 45 & 59.4 & 444 & 32 & 226.0 \\
\hline & 1760 & 45 & 29.7 & 1547 & 46 & 46. 8 & 1227 & 44 & 87.5 & 929 & 38 & 109. 6 \\
\hline & 571 & 32 & 17.4 & 970 & 41 & 39.4 & 1281 & 42 & 63.5 & 933 & 40 & 40.4 \\
\hline & 630 & 34 & 23.5 & 1617 & 42 & 73. 8 & 1263 & 44 & 67.2 & 802 & 38 & 66. 3 \\
\hline & 454 & 29 & 24. 2 & 361 & 29 & 42.5 & 1186 & 41 & 91.7 & 1170 & 42 & 54. 1 \\
\hline & 1863 & 45 & 13.4 & 765 & 36 & 35.0 & 1163 & 40 & 120.3 & 785 & 38 & 80.3 \\
\hline & 1659 & 46 & 26. 9 & 1709 & 44 & 47.4 & 1494 & 42 & 81.5 & 582 & 34 & 124. 2 \\
\hline & 973 & 38 & 24.1 & 1275 & 45 & 51.4 & 1313 & 40 & 71.8 & & & \\
\hline & 1973 & 46 & 29.1 & & & & & & & & & \\
\hline & 1674 & 45 & 32.7 & & & & & & & & & \\
\hline Mean & 1123 & 38 & 24.3 & 1055 & 39 & 49. 1 & 1190 & 42 & 75.0 & 896 & 38 & 85.9 \\
\hline 2XSE & 260 & 3 & 2.2 & 235 & 3 & 6.6 & 72 & 1 & 8.7 & 203 & 3 & 26.6 \\
\hline
\end{tabular}


Table B2. Comparative standard (S) and resting routine (RR), mass-independent 0 , consumption rates $\left(\mathrm{MO}, \mathrm{mg} \mathrm{O}_{2} \cdot \mathrm{kg}^{-\mathbf{2 / 3}} \cdot \mathrm{h}^{-1}\right.$ ) for several freshwater fishes at various temperatures $\left({ }^{\circ} \mathrm{C}\right)$.

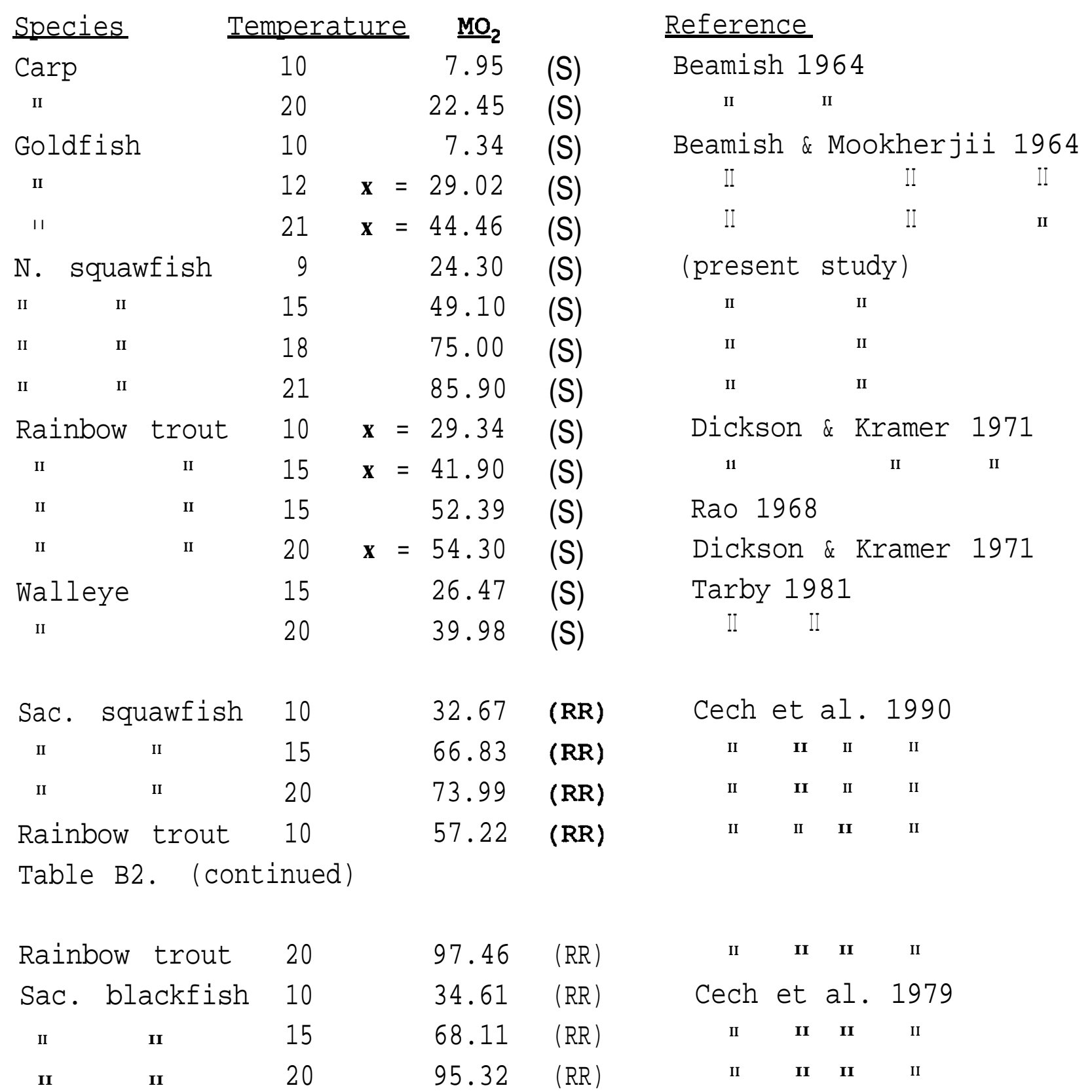

